\title{
A review of potential contaminants in Australian livestock feeds and proposed guidance levels for feed
}

\author{
D. J. MacLachlan A,G , B. J. Blaney ${ }^{\mathrm{B}}$, L. G. Cook ${ }^{\mathrm{C}}$, E. Klim $^{\mathrm{A}}$, R. Scholl ${ }^{\mathrm{D}}$, M. Sexton $^{\mathrm{E}}$, \\ J. Spragg ${ }^{\mathrm{F}}$ and R. Watts ${ }^{\mathrm{D}}$ \\ ADepartment of Agriculture, Fisheries and Forestry, GPO Box 858, Canberra, ACT 2601, Australia. \\ ${ }^{B}$ PO Box 367, Maleny, Qld 4552, Australia. \\ C NSW Department of Primary Industries, Locked Bag 21, Orange, NSW 2800, Australia. \\ ${ }^{D}$ Queensland Department of Agriculture, Fisheries and Forestry, GPO Box 46, Brisbane, Qld 4001, Australia \\ ${ }^{E}$ Department of Agriculture and Food Western Australia, PO Box 1231, Bunbury, WA 6231, Australia. \\ FStock Feed Manufacturers' Council of Australia, PO Box 383, Beaconsfield, Vic. 3807, Australia. \\ ${ }^{\mathrm{G}}$ Corresponding author. Email: dugald.maclachlan@daff.gov.au
}

\begin{abstract}
Contaminants of man-made and natural origin need to be managed in livestock feeds to protect the health of livestock and that of human consumers of livestock products. This requires access to information on the transfer from feed to food to inform risk profiles and assessments, and to guide management interventions such as regulation or Hazard Analysis Critical Control Point approaches. This paper reviews contaminants of known and potential concern in the production of livestock feeds in Australia and compares existing but differing state and national regulatory standards with international standards. The contaminants considered include man-made organic chemical contaminants (e.g. legacy pesticides), elemental contaminants (e.g. arsenic, cadmium, lead), phytotoxins (e.g. gossypol) and mycotoxins (e.g. aflatoxins). Reference is made to scientific literature and evaluations by regulators to propose maximum levels that can be used for guidance by those involved in managing contamination incidents or developing feed safety programs.
\end{abstract}

Received 10 February 2012, accepted 6 September 2012, published online 8 January 2013

\section{Introduction}

Contaminants in feed for livestock need to be managed to protect livestock health, and to minimise residues in livestock products that might affect the health of human consumers or impair marketing and international trade. Contaminants can arise from man-made organic chemical sources such as pesticides, from environmental sources of contamination (Gilbert and Şenyuva 2005), or from natural toxins present in plants (phytotoxins) and fungi (mycotoxins) (Blaney 2005). Feed contamination has caused major food safety incidents in Europe, such as dioxin and polychlorinated biphenyl (PCB) contamination of poultry products in Belgium and lead in feed of dairy cattle in the Netherlands (Baars et al. 1992; Covaci et al. 2008). On several occasions Australian livestock producers and government authorities have also had to deal with feed and environmental contamination affecting trade, but these incidents have generally been well managed and no significant risks to human health have resulted. To maintain this record requires that systems for control and management of feed safety should be periodically reevaluated and strengthened where necessary.

Regulation by government has been for many years a key process for managing contaminants and is likely to remain so where there are perceived risks to human health. Where the risks are primarily to livestock production and to trade, government policy is trending towards industry self-regulation. Feed safety systems should aim to ensure that food derived from animals is suitable for human consumption. This is achieved by adherence to good animal feeding practice at the farm level, and good manufacturing practices during procurement, handling, storage, processing and distribution of animal feed, feed additives and feed ingredients. One suitable process for such management is that of Hazard Analysis Critical Control Point, a systematic approach to the identification, assessment and control of hazards in the food chain. However, in many instances the information necessary to assess the risk of various contaminants is not readily accessible, hampering attempts to use pre-emptive risk management strategies.

The aim of the present paper is to review knowledge of contaminants in Australia, and to then recommend guidance maximum levels for livestock feed used for food-producing species. This will improve compliance with human food standards and minimise risks to consumers' health, to livestock health and productivity, to trade in animal products, and to trade in animal feed. The scope of the paper is limited to cattle, sheep, goats, pigs and poultry, the main livestock species used in Australia to produce food.

The main classes of contaminants of feed considered here are:

(1) Man-made organic chemical contaminants (e.g. dieldrin, dioxins);

(2) Elemental contaminants (e.g. arsenic, cadmium, lead, mercury); 
(3) Phytotoxins (e.g. gossypol); and

(4) Mycotoxins (e.g. aflatoxin B1)

Guidance levels for contaminants should be set at concentrations in animal feeds such that their use will not result in violations of the current regulatory standards for food of animal origin (edible tissues, milk or eggs). A recent literature review has summarised factors for the transfer of contaminants from feed to tissues, milk or eggs (MacLachlan 2011). The reported transfer factors (TFs), sometimes also known as concentration ratios, can be used to estimate guidance levels for feed. They are based on long-term exposure of livestock to a contaminant such that the levels in tissues, milk or eggs approach a constant value with time.

$$
\mathrm{TF}_{\mathrm{i}}=\mathrm{C}_{\mathrm{i}} / \mathrm{C}_{\text {feed }}
$$

where $C_{i}$ is the contaminant concentration in the animal commodity of interest (muscle, fat, liver, kidney, milk, eggs) with units $\mathrm{mg} / \mathrm{kg}$ fresh weight and $\mathrm{C}_{\text {feed }}$ is the contaminant concentration in the animal diet ( $\mathrm{mg} / \mathrm{kg} \mathrm{DM})$.

The TF can be used to calculate the concentration of a contaminant in feed that will lead to a particular level in tissues, milk or eggs.

$$
\begin{aligned}
\mathrm{C}_{\text {feed }} & =\mathrm{C}_{\mathrm{i}} /\left(\mathrm{R} \times \mathrm{TF}_{\mathrm{i}}\right) \text { where } \mathrm{i} \\
& =\text { fat, muscle, liver, kidney, milk or eggs }
\end{aligned}
$$

where $\mathrm{R}$ = bioavailability of the source relative to material used in transfer studies and bioavailability is the fraction ingested that is absorbed (if unknown it is assumed $\mathrm{R}=1$ ).

In recommending guidance levels for livestock feeds, consideration should be given to existing industry-based standards and government regulations. Where possible, the proposed guidance levels should harmonise existing regulations and industry standards.

\section{Man-made organic chemical contaminants}

A range of man-made organic chemicals can be found in livestock feeds such as pesticides applied to crops that might consequently be used as feed, the carry-over of veterinary medicine residues from medicated to non-medicated feed and the contamination of feed with chemicals found in the environment. Compounds that have both natural and man-made sources are also included in this section (dioxins, polycyclic aromatic hydrocarbons, PAH). The health of livestock is usually unaffected at the concentrations found in feeds; rather it is the transfer to food of animal origin (tissues, milk and eggs) that is of concern.

Agricultural pesticides and veterinary medicines are assessed as part of the regulated registration process by the Australian Pesticides and Veterinary Medicines Authority (APVMA). The registration process includes consideration of the potential for residues in livestock arising from residues in feed. The livestock industry has conducted additional assessments for these compounds based on either meeting or reducing the risk of not complying with differing standards in export markets. Consequently, it is considered that current pesticides and veterinary medicines are adequately addressed within the current system (MacLachlan and Bhula 2008; Lutze et al. 2009).
Because of their intake of pasture and roughages as well as possible ingestion of contaminated soil ruminants (cattle, sheep and goats) are vulnerable to background environmental contamination. In contrast, pigs and poultry (as well as lot-fed cattle and sheep) are fed controlled diets and are more susceptible to contaminated feed ingredients such as feed additives used in manufactured feed.

The continued legacy of organochlorine pesticides in the environment resulting from legal usage many years ago in Australia, as well as their ongoing use in some countries, can cause exposure through feed and result in their accumulation in fatty tissues, milk and eggs of livestock. The main source of exposure in Australia is through access by livestock to historically contaminated land rather than traded feed (Robertson et al. 1990). Cattle are the main species affected and residues in beef cost the industry hundreds of millions of dollars in testing costs and lost trade in the 1980s and 1990s (Shaw and Eustace 1993). Since then residues are adequately controlled through the National Organochlorine Residue Management program and on-farm risk assessments conducted as part of the industry on-farm food safety and quality assurance programs (LPA 2011). Additional exposure through manufactured feeds should be controlled to ensure residues are minimised.

Table 1 lists maximum limits (MLs) for food of animal origin for various man-made organic chemical contaminants and includes levels for Australia and major markets for Australian livestock commodities. As $60-70 \%$ of Australian production of beef and sheep meat is exported, it is important that guidance levels for feed minimise the risk of exceeding standards in major markets.

\section{Organochlorine pesticides}

Maximum levels for persistent organochlorine pesticides (DDT, dieldrin, hexachlorobenezene, heptachlor and lindane) in feed have been established by individual states and territories within Australia (Vic. 1992; Qld 1997; WA 2006; NSW 2010) and are consistent with the production of food that will comply with relevant MLs in the Australia New Zealand Food Standards Code (the Food Code). Similar values for stock feed are listed in the APVMA MRL Standard. International maximum residue limits (MRLs) for persistent organochlorine pesticides in food are similar to the Australian values. Monitoring conducted by the National Residue Survey (NRS) indicates that detectable residues in species other than cattle are infrequent $(<0.1 \%)$, and non-compliant residues are rare in all species.

The current standards in Australia for livestock feed in the APVMA MRL Standard are suitable with the exception of mirex for which no standard has been established. A TF for mirex in fat of 1.9 has recently been reported (MacLachlan 2011). Relative bioavailability is assumed to be one. If encountered in feed, making use of Eqn 2 it is suggested that levels of mirex in the total diet be less than $0.01 \mathrm{mg} / \mathrm{kg} \div 1.9=0.005 \mathrm{mg} / \mathrm{kg} \mathrm{DM}$ to ensure the concentration in fat of exposed animals is less than 0.01 $\mathrm{mg} / \mathrm{kg}$, a default concentration applied in several markets including the EU and Japan. 
Table 1. Maximum limits and action levels (mg/kg wet weight except dioxins, which are on a $\mathrm{ng} \mathrm{TEQ} \mathrm{Q}^{\mathrm{A}} / \mathrm{kg}$ fat basis and indicator $\mathrm{PCBs}$, which are on a $\mu \mathrm{g} / \mathrm{kg}$ fat basis) for man-made organic chemical contaminants in various countries and regions

$\mathrm{c}=$ cattle, $\mathrm{p}=$ pigs, $\mathrm{po}=$ poultry, $\mathrm{ch}=$ chicken, $\mathrm{b}=$ beef, $\mathrm{s}=$ sheep, fat $=$ residue should be measured in trimable fat in the case of meat and in mechanically separated milk fat in the case of whole milk, $\mathrm{F}=$ the residue is fat soluble and when measured on a milk fat basis would be up to $25 \times$ higher

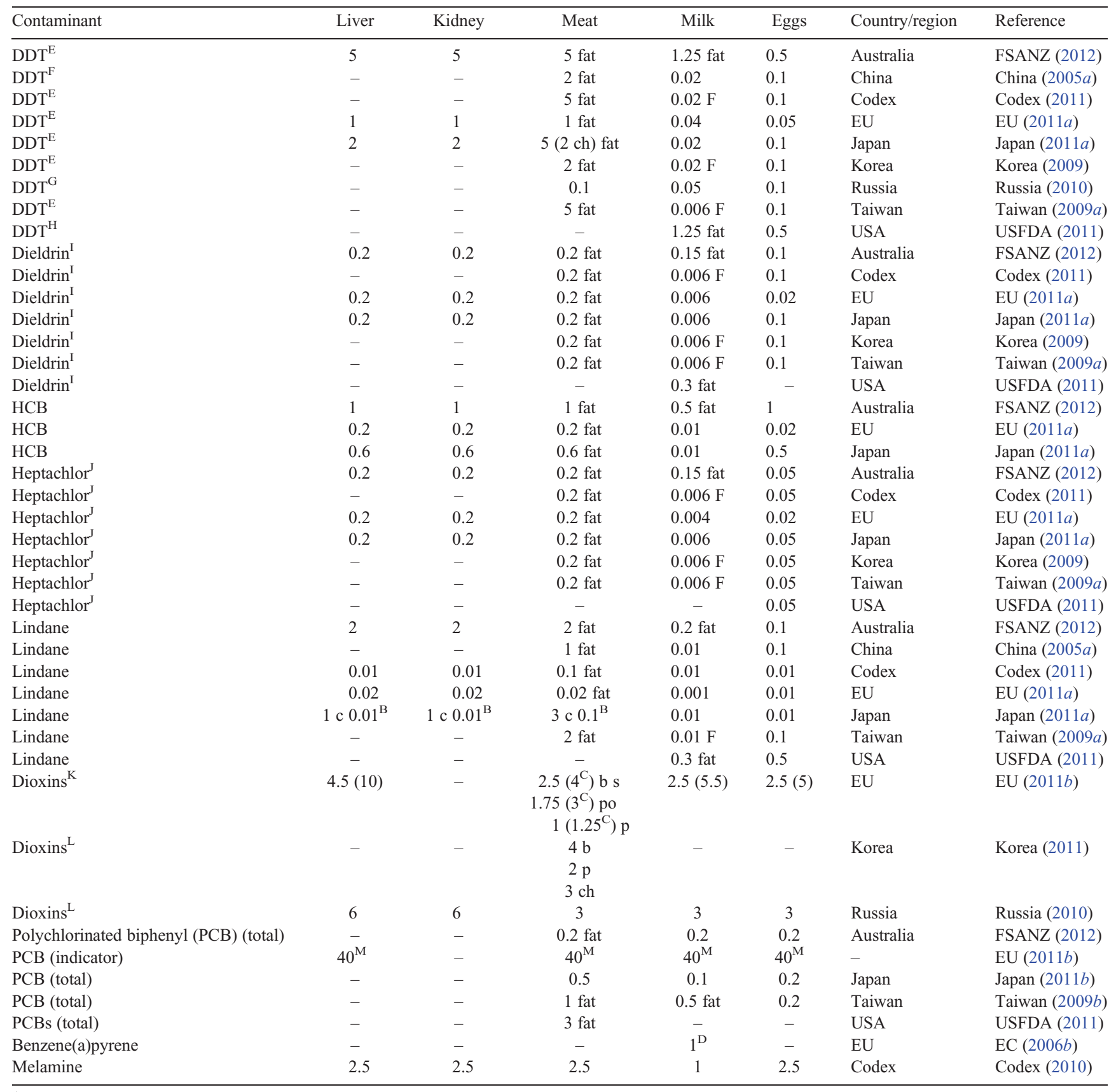

${ }^{\mathrm{A}}$ Dioxins and dioxin-like (dl)-PCB are regulated as a group using the concept of toxic equivalents (TEQ). To obtain the residue expressed in terms of TEQ, the concentrations for individual congeners are multiplied by the congener toxic equivalency factor (TEF) and summed, i.e. $\Sigma\left(C_{i} \times T_{E F}\right)$.

${ }^{B}$ All other species. ${ }^{C}$ Figures in brackets are limits including dl-PCB. ${ }^{D}$ Infant milk. ${ }^{\mathrm{E}}$ Sum of $\mathrm{p}, \mathrm{p}^{\prime}-\mathrm{DDT}+\mathrm{o}, \mathrm{p}^{\prime}-\mathrm{DDT}+\mathrm{p}, \mathrm{p}^{\prime}-\mathrm{DDE}+\mathrm{p}, \mathrm{p}^{\prime}-\mathrm{DDD}$.

${ }^{\mathrm{F}}$ Sum of p,p'-DDT + p,p'-DDE, + p,p'-DDD. ${ }^{\mathrm{G}}$ Sum of DDT and its metabolites. ${ }^{\mathrm{H}}$ Sum of DDT, DDE and DDD. 'Sum of HHDN + HOED.

'Sum of heptachlor + heptachlor epoxide expressed as heptachlor.

${ }^{\mathrm{K}}$ WHO TEF for human risk assessment based on the conclusions of the World Health Organisation meeting in Geneva, Switzerland in June 2005 as listed in van den Berg et al. (2006).

${ }^{\mathrm{L}}$ WHO TEF for human risk assessment based on the conclusions of the World Health Organisation meeting in Stockholm, Sweden, 15-18 June 1997 as listed in van den Berg et al. (1998).

${ }^{\mathrm{M}} \mathrm{Sum}$ of PCB28 + PCB52 + PCB101 + PCB138 + PCB153 + PCB180. 


\section{Dioxin and dioxin-like polychlorinated biphenyls}

Contamination of feed and feed ingredients with dioxins and dioxin-like PCBs (dl-PCBs) has caused billions of dollars of damage to livestock producers in Europe, the USA and Chile in the last 30 years (Buzby and Chandran 2003; Kim et al. 2009; Heres et al. 2010; Alcoser et al. 2011). Dioxins can be present in feed due to both natural and man-made sources (Fries 1995). Sources of contamination have included ball clay used as an anticaking agent in feed, lime as a neutralisation agent for citrus pulp, waste oil, choline chloride, zinc and copper oxides, gelatine, recycled oil and contaminated oils containing PCB used to heat air for drying bread crumbs and maize, and most recently contaminated fatty acids. In none of these cases was the contamination foreseen.

The public health and safety risk for Australians from exposure to dioxins from foods is very low and there are no Australian standards for dioxins and dl-PCBs in foods of animal origin or in animal feeds (FSANZ 2004). Several major markets for Australian exports have established MLs for animal commodities with many of the standards similar to those of the EU (EU 2011b). While the risk of dioxins in Australian livestock is considered low (DAFF 2004) it is advisable that feed ingredients be monitored against the MLs present in the EU to ensure levels of dioxins are as-low-as-reasonably-achievable (EC 2006a). It should be noted that the transfer of dioxin residues into food of animal origin depends on the congener profile of the feed. TF for typical environmental sources of dioxins present in feed for cattle, pig and chicken fat are estimated to be 5.3, 3.7 and 8.8, respectively, (MacLachlan 2011) suggesting levels in the total diet should be kept below $0.5 \mathrm{ng}$ toxic equivalents (TEQ) $/ \mathrm{kg}$ for cattle, $0.3 \mathrm{ng} \mathrm{TEQ} / \mathrm{kg}$ for pigs and $0.2 \mathrm{ng} \mathrm{TEQ} / \mathrm{kg}$ for poultry. These values are lower than the EU ML of $1.5 \mathrm{ng}$ TEQ/ $\mathrm{kg}$ for the total diet. The maximum level of dioxins that can be accommodated in the diet and for which derived food of animal origin will comply with EU standards will depend on the congener profile of the dioxin residue as well as bioavailability.

\section{Polychlorinated biphenyls}

Following exposure of cattle to feed containing PCBs in general, concentrations in fat can be 4.3 times greater than in feed (MacLachlan 2011) suggesting PCBs should not be present in the total diet at levels greater than $0.05 \mathrm{mg} / \mathrm{kg}(0.2 \mathrm{mg} / \mathrm{kg} \div 4.3=$ $0.047 \mathrm{mg} / \mathrm{kg}$ ).

\section{Polybrominated biphenyls}

The standard in New South Wales (NSW 2010) and Western Australia (WA 2006) for polybrominated biphenyls (PBBs) is nil for manufactured stock foods. No standards have been established in the Food Code for PBBs in food. European Food Safety Authority (EFSA) concluded that health-based standards were not required for PBBs (EFSA 2010a). At this stage it does not seem justified to recommend a guidance level for PBB given their ubiquitous presence in the environment and the lack of a human health concern.

\section{Other man-made organic compounds}

A few substances are of potential concern because of their widespread usage in human communities and ability to produce residues in food of unknown health risk. These include acrylamide, chlorinated paraffins, melamine, mineral hydrocarbons, perfluorinated alkanes, phthalates, polybrominated flame retardants and PAHs. Of these, standards for food of animal origin have only been established internationally for PAHs and melamine.

Benzo[a]pyrene has been used in the $\mathrm{EU}$ as a marker for $\mathrm{PAH}$ residues in food (EC 2006b). The transfer of benzo[a]pyrene to tissues, milk and eggs is negligible and as such guidance levels are not required for feed. However, hydroxylated metabolites of PAHs are found at significant concentrations in tissues, milk and eggs of exposed animals and if regulatory concern shifts to include hydroxylated metabolites guidance levels may be required.

The Codex Committee on Contaminants in Food has recommended an ML for melamine in animal feed of $2.5 \mathrm{mg} / \mathrm{kg}$, noting that the ML applies to levels of melamine resulting from its non-intentional and unavoidable presence in feed (Codex 2010). The ML does not apply to feed for which it can be proven that concentrations of melamine higher than $2.5 \mathrm{mg} / \mathrm{kg}$ are the consequence of either the authorised use of cyromazine as an insecticide, or derived from the legitimate use of the feed ingredients guanidino acetic acid, urea and biuret. Transfer studies with lactating dairy cows indicate concentrations in milk and tissues are not expected to exceed maximum levels set by the Codex Alimentarius Commission (Codex) when feed contains concentrations of up to $30 \mathrm{mg} / \mathrm{kg}$ feed, a substantial margin of safety. The limit established by Codex for feed is based on residues being as-low-as-reasonably-achievable. The maximum level is also below that which might result in an adverse effect on livestock production as noted in a recent review of the literature by the EFSA $(2010 b)$. This review concluded that exposures to melamine and related compounds individually at scenarios of up to $10 \mathrm{mg} / \mathrm{kg}$ in feed are well below the doses causing toxicity and are therefore not expected to pose a risk to livestock.

State and APVMA MLs and proposed guidance maximum levels for legacy pesticides and environmental contaminants are summarised in Table 2.

\section{Elemental contaminants}

Food safety authorities have established MLs for a small number of elements in a variety of foods, including animal commodities when these are major contributors to human exposure. Human health risks arise from the persistence and accumulation of these elements in human tissues until a toxic threshold is reached. The major elements of concern for livestock health and/or residues in meat are cadmium, lead, mercury, arsenic, fluorine and potentially chromium, nickel, copper, zinc, selenium and molybdenum. The 20th Australian Total Diet Survey (FSANZ 2003) investigated the dietary exposure of the Australian population to different elements: antimony, arsenic, cadmium, lead, mercury, copper, selenium, zinc and tin, the 22nd Australian Total Diet Survey (FSANZ 2008) investigated chromium, molybdenum, nickel and selenium while the 23rd Australian 
Table 2. Current state or Australian Pesticide and Veterinary Medicines Authority (APVMA) maximum limits (MLs) and recommended guidance maximum levels for man-made organic chemical contaminants in feed

$\mathrm{n}=$ New South Wales; $\mathrm{q}=$ Queensland; $\mathrm{v}=$ Victoria; $\mathrm{w}=$ Western Australia

\begin{tabular}{|c|c|c|c|}
\hline Contaminant & Feed & $\begin{array}{c}\text { State or } \\
\text { APVMA ML } \\
(\mathrm{mg} / \mathrm{kg} \mathrm{DM})\end{array}$ & $\begin{array}{c}\text { Recommended } \\
\text { guidance maximum } \\
\text { level }(\mathrm{mg} / \mathrm{kg} \mathrm{DM})\end{array}$ \\
\hline Aldrin $(\Sigma$ HHDN + HEOD) & Total diet & $0.01 \mathrm{nqvw}$ & 0.01 \\
\hline BHC (other than $\gamma$-BHC) & Total diet & 0.02 nqvw & 0.02 \\
\hline Chlordane & Total diet & $0.01 \mathrm{nqvw}$ & 0.01 \\
\hline $\mathrm{DDT}^{\mathrm{A}}$ & Total diet & $0.05 \mathrm{nqvw}$ & 0.05 \\
\hline Dieldrin $(\Sigma$ HHDN + HEOD) & Total diet & $0.01 \mathrm{nqvw}$ & 0.01 \\
\hline Endrin & Total diet & 0.03 nqvw & 0.03 \\
\hline $\mathrm{HCB}$ & Total diet & $0.01 \mathrm{nqvw}$ & 0.01 \\
\hline Heptachlor $(\Sigma$ heptachlor + epoxide $)$ & Total diet & $0.02 \mathrm{nqvw}$ & 0.02 \\
\hline Lindane $(=\gamma-\mathrm{BHC})$ & Total diet & $0.1 \mathrm{nqvw}$ & 0.1 \\
\hline Mirex & Total diet & - & 0.005 \\
\hline Sum of the adulterants listed & Total diet & $0.1 \mathrm{nqw}$ & 0.1 \\
\hline PBB $(\Sigma$ congeners $)$ & Total diet & $0 \mathrm{nw}$ & - \\
\hline Polychlorinated biphenyl (PCB) ( $\Sigma$ congeners) & Total diet & $0.05 \mathrm{nw}$ & 0.05 \\
\hline \multirow[t]{9}{*}{ Dioxins + dl-PCBs $(\Sigma \text { TEQ })^{\mathrm{B}}$} & Total diet for cattle, sheep, goats & - & $0.5 \mathrm{ng} \mathrm{TEQ} / \mathrm{kg} \mathrm{DM}$ \\
\hline & Total diet for pigs & - & $0.3 \mathrm{ng} \mathrm{TEQ} / \mathrm{kg} \mathrm{DM}$ \\
\hline & Total diet for poultry & - & $0.2 \mathrm{ng} \mathrm{TEQ} / \mathrm{kg} \mathrm{DM}$ \\
\hline & Feed ingredients except as below: & - & $1.25 \mathrm{ng} \mathrm{TEQ} / \mathrm{kg} \mathrm{DM}$ \\
\hline & $\begin{array}{l}\text { Vegetable oils, minerals, trace elements, } \\
\text { premixes, anti-caking agents and binders }\end{array}$ & - & $1.5 \mathrm{ng} \mathrm{TEQ} / \mathrm{kg} \mathrm{DM}$ \\
\hline & Animal fats, milk fats, egg fats & - & 3 ng TEQ/kg DM \\
\hline & $\begin{array}{l}\text { Fish, other aquatic animals and their products } \\
\text { except as below: }\end{array}$ & - & $4.5 \mathrm{ng} \mathrm{TEQ} / \mathrm{kg} \mathrm{DM}$ \\
\hline & Fish oil & - & 24 ng TEQ/kg DM \\
\hline & Fish protein hydrolysates with $>20 \%$ fat & - & $11 \mathrm{ng} \mathrm{TEQ} / \mathrm{kg} \mathrm{DM}$ \\
\hline Melamine & Total diet & - & 2.5 \\
\hline
\end{tabular}

${ }^{\mathrm{A}} \mathrm{DDT}=\Sigma\left(\mathrm{p}, \mathrm{p}^{\prime}-\mathrm{DDT}+\mathrm{o}, \mathrm{p}^{\prime}-\mathrm{DDT}+\mathrm{p}, \mathrm{p}^{\prime}-\mathrm{DDE}+\mathrm{p}, \mathrm{p}^{\prime}-\mathrm{DDD}\right)$.

${ }^{\mathrm{B}}$ Dioxins and dioxin-like-PCBs are regulated as a group using the concept of toxic equivalents (TEQ). To obtain the residue expressed in terms of TEQ, the concentrations for individual congeners are multiplied by the congener toxic equivalency factor (TEF) and summed, i.e. $\Sigma\left(\mathrm{C}_{\mathrm{i}} \times \mathrm{TEF}_{\mathrm{i}}\right)(\mathrm{van}$ den Berg et al. 2006).

Total Diet Survey (FSANZ 2011) included arsenic, chromium, cadmium, copper, fluoride, lead, mercury, selenium, and zinc. In all cases FSANZ concluded there was no evidence to suggest that intakes of these elements by the Australian population exceeded safe levels.

Like all potentially toxic elements, these elements are also tolerated only up to a certain limit by animals. Above that limit, their intrinsic toxic potential leads to detrimental effects. Exposure to, and requirement for, elements are influenced by factors such as the class of animal, level of production, chemical form of the element, mineral interrelationships, dietary intake, breed differences and adaptation on long-term exposure. The National Research Council (NRC) of the USA has established maximum tolerable levels (MTLs) for different minerals in the diets of livestock. These MTLs are the 'dietary level that, when fed for a defined period of time, will not impair animal health or performance' (NRC 2005).

Table 3 lists MLs for food of animal origin for various chemical elements and includes levels for Australia and major markets for Australian livestock commodities together with Generally Expected Levels (GELs) (90th percentiles). The latter have been proposed by FSANZ to assist food manufacturers in ensuring concentrations of these contaminants are as-low-as-reasonablyachievable (FSANZ 2001). Concentrations above the GEL should prompt an investigation to determine whether or not samples contain consistently high concentrations and to investigate whether management changes can be implemented to reduce these. Concentrations above the GEL do not indicate the food is unsafe.

The following discussion concentrates only on ensuring compliance with established MLs and GELs (90th percentiles). The use of some chemical elements such as copper and chromium for growth promotion, or zinc as a medication, is not considered. In calculation of guidance maximum levels for feed, TFs were taken from the recent review by MacLachlan (2011). When recommending maximum levels for the total diet of livestock the bioavailability of elements in feed relative to the forms used in studies on the transfer to tissues, milk and eggs was assumed to be 1.0 .

\section{Antimony}

Concentrations of antimony in the environment are low with major sources associated with mining and application of biosolids to agricultural land (NRC 2005). Only low concentrations of antimony have been found in monitoring studies of meat (NRS 1997). TFs of 0.18 have been reported for cattle kidney and muscle (MacLachlan 2011). FSANZ have recommended GELs 
Table 3. Maximum limits and 90th percentile Generally Expected Levels (GELs, $\mathrm{mg} / \mathrm{kg}$ wet weight) for various elements in livestock commodities in various countries or regions ${ }^{\mathrm{A}}$

$\mathrm{s}=$ sheep, $\mathrm{ch}=$ chicken

\begin{tabular}{|c|c|c|c|c|c|c|c|}
\hline Element & Liver & Kidney & Meat & Milk & Eggs & Country/region & Reference \\
\hline Antimony & 0.05 & 0.05 & 0.05 & - & - & Australia (GEL) & FSANZ (2001) \\
\hline Arsenic $^{\mathrm{B}}$ & $0.1(1 \mathrm{ch})$ & 0.1 & 0.02 & - & - & Australia (GEL) & FSANZ (2001) \\
\hline Arsenic $^{\mathrm{B}}$ & - & - & 0.5 & 0.1 & - & China & China $(2005 b)$ \\
\hline Arsenic $^{\mathrm{B}}$ & & & 0.1 fat & - & - & Codex & Codex (2010) \\
\hline Arsenic $^{\mathrm{B}}$ & 1 & 1 & 0.1 & 0.05 & 0.1 & Russia & Russia (2010) \\
\hline Cadmium & 1.25 & 2.5 & 0.05 & - & - & Australia & FSANZ (2012) \\
\hline Cadmium & 0.5 & 1 & 0.1 & - & 0.05 & China & China $(2005 b)$ \\
\hline Cadmium & 0.5 & 1 & 0.05 & - & - & EU & EC $(2006 b)$ \\
\hline Cadmium & 0.3 & 1 & 0.05 & 0.03 & 0.01 & Russia & Russia (2010) \\
\hline Chromium & 1 & 1 & 1 & 0.3 & 1 & China & China $(2005 b)$ \\
\hline Copper & $50(150 \mathrm{~s})$ & 50 & 2 & - & - & Australia (GEL) & FSANZ (2001) \\
\hline Lead & 0.5 & 0.5 & 0.1 & - & - & Australia & FSANZ (2012) \\
\hline Lead & 0.5 & 0.5 & 0.2 & 0.05 & 0.2 & China & China $(2005 b)$ \\
\hline Lead & 0.5 & 0.5 & 0.1 & 0.02 & - & Codex & Codex (2010) \\
\hline Lead & 0.5 & 0.5 & 0.5 & 0.02 & - & $\mathrm{EU}$ & EC (2006b) \\
\hline Lead & 0.6 & 1.0 & 0.5 & 0.1 & 0.3 & Russia & Russia (2010) \\
\hline Lead & 0.5 & 0.5 & - & - & - & Taiwan & Taiwan $(2009 c)$ \\
\hline Mercury & 0.01 & 0.01 & 0.01 & - & - & Australia (GEL) & FSANZ (2001) \\
\hline Mercury & - & - & 0.05 & 0.01 & 0.05 & China & China $(2005 b)$ \\
\hline Mercury & 0.1 & 0.2 & 0.03 & 0.005 & 0.02 & Russia & Russia (2010) \\
\hline Selenium & 2 & 2 & 0.2 & - & - & Australia (GEL) & FSANZ (2001) \\
\hline Zinc & 60 & 60 & 75 & - & - & Australia (GEL) & FSANZ (2001) \\
\hline
\end{tabular}

${ }^{\mathrm{A}}$ Japan, the Republic of Korea and the USA have not established limits for the metals listed in livestock commodities.

${ }^{\mathrm{B}}$ Total arsenic.

of $0.05 \mathrm{mg} / \mathrm{kg}$ for meat of cattle, pigs and sheep and $0.05 \mathrm{mg} / \mathrm{kg}$ for edible offal of cattle, pigs and sheep (Table 3). To have confidence that concentrations in tissues will be below the 90th percentile GEL in Australia, it is recommended that concentrations in feed should not exceed $0.05 \mathrm{mg} / \mathrm{kg} \div 0.18=$ $0.28 \mathrm{mg} / \mathrm{kg} \mathrm{DM}$. On rounding the guidance maximum level is $0.3 \mathrm{mg} / \mathrm{kg} \mathrm{DM}$ for antimony in the total diet of cattle, pigs and sheep.

\section{Arsenic}

Sources of arsenic for grazing livestock include contaminated land associated with its historic use as an acaricide for tick control, and some natural outcrops of arsenical mineral deposits. However, only low concentrations of arsenic in livestock products have been found in monitoring studies (NRS 1997). The transfer of arsenic from feed to tissues, milk and eggs depends on the arsenic compound administered, animal species and duration of exposure. TFs of 0.091 and 0.13 for total arsenic have been reported for cattle muscle and cattle milk, respectively (MacLachlan 2011). FSANZ have recommended 90th percentile GELs of $0.02 \mathrm{mg} / \mathrm{kg}$ for meat of cattle, pigs and sheep, $0.1 \mathrm{mg} / \mathrm{kg}$ for edible offal of cattle, pigs and sheep and $1 \mathrm{mg} / \mathrm{kg}$ for liver of chickens (Table 3). To have confidence that concentrations in muscle are below the GEL in Australia, concentrations in feed should not exceed $0.02 \mathrm{mg} / \mathrm{kg} \div 0.091$ $=0.2 \mathrm{mg} / \mathrm{kg}$ DM. For lactating animals, concentrations of arsenic in feed should be below $0.05 \mathrm{mg} / \mathrm{kg} \div 0.13=0.4 \mathrm{mg} / \mathrm{kg}$ DM to be confident concentrations in milk will be below the standard in Russia. Since the estimated level for meat animals is lower than that required for lactating animals, the maximum level proposed for cattle, pigs and sheep feeds is $0.2 \mathrm{mg} / \mathrm{kg} \mathrm{DM}$.

\section{Cadmium}

Cadmium is a ubiquitous contaminant that is present in many feed and feed ingredients (EFSA 2004a). The main source of livestock exposure for animals produced under extensive systems is through the environment (forage and soil) while for production under intensive systems the major sources are feed ingredients (EFSA 2004a).

Grain-based feed materials generally contain low concentrations of cadmium. Data on the cadmium content of several cereal grain, pulse and oilseed feed materials have been reported (NRS, pers. comm.). In most (>99.9\%) samples cadmium was not detected above the limit of reporting of $0.01 \mathrm{mg} / \mathrm{kg}$. Cadmium impurities can be present in mineralbased feed materials such as phosphates including phosphatic fertilisers, and can be a significant contributor to livestock dietary intake (EFSA 2004a).

Cadmium disposition is significantly influenced by dietary interactions with zinc, copper, iron and calcium (Suttle 2010). Ascorbic acid and cholecalciferol can influence the rate of absorption. Additionally, the absorption of dietary cadmium depends on the cadmium concentration in individual feed materials, time and frequency of exposure, the animal species, animal age or stage of development, and nutritional status of the animal (Suttle 2010).

As environmental cadmium exposure for grazing animals can be substantial, additional exposure through manufactured feeds 
should be controlled and kept to a minimum to reduce the chance that tissue concentrations exceed MLs in tissues at slaughter. Little data is available on cadmium concentrations in feed additives used in Australia, however many feed additives are traded internationally and information is available from a recent EFSA review (EFSA 2004a). Cadmium contents of mineral supplements and premixtures ranged from $<0.01$ to $2.3 \mathrm{mg} / \mathrm{kg}$ DM with a mean value of $0.6 \mathrm{mg} / \mathrm{kg} \mathrm{DM}$.

Advice on maximum levels for exposure to cadmium are challenging to develop as cadmium accumulates with increasing duration of exposure, and the slaughter of livestock usually occurs before steady-state concentrations are achieved in tissues. In this case the use of a TF is not ideal. Additionally the Australian ML for cadmium for kidney and liver listed in the Food Code (FSANZ 2012) are higher than those for some significant markets.

Concentrations of cadmium in the total diet should be as-lowas-reasonably-achievable and for ruminants not greater than $1 \mathrm{mg} / \mathrm{kg}$ DM. Based on the results of the EFSA review, levels are also proposed as listed in Table 4 for cadmium in various feed ingredients.

Australia has developed a strategy to reduce the concentrations of cadmium found in meat and meat products which should assist producers in keeping cadmium tissue concentrations as-low-asreasonably-achievable (Safemeat 2007).

\section{Chromium}

While naturally present in the environment at low concentrations, phosphate added to rations is thought to be the major source of chromium in livestock diets (NRC 2005; Suttle 2010). Chromium is also sometimes added to diets as a supplement (Suttle 2010). The absorption of $\mathrm{Cr}$ (III) is poor and tissue residues are generally very low (NRC 2005; Suttle 2010). There are no specific regulations on maximum levels of chromium in foods in Australia. China has established standards at $1 \mathrm{mg} / \mathrm{kg}$ wet weight (WW) for liver, kidney, muscle and eggs and $0.3 \mathrm{mg} / \mathrm{kg}$ for milk. Using a TF for cattle liver of 0.055 (MacLachlan 2011), it is recommended that the maximum level at which chromium should be incorporated into the total diet for compliance with the standard in China should be $18 \mathrm{mg} / \mathrm{kg} \mathrm{DM}(1 \mathrm{mg} / \mathrm{kg} \div 0.055=18$ $\mathrm{mg} / \mathrm{kg}$ ), which can be rounded to $20 \mathrm{mg} / \mathrm{kg} \mathrm{DM}$.

\section{Copper}

Apart from deliberate feed supplementation, sources of copper for livestock include mineral deposits, fertilisers, and its use to control fungi in crops, preserve wood, and control cyanobacteria in water supplies (NRC 2005; Suttle 2010). Copper absorption and utilisation by livestock can be markedly affected by several mineral elements and other dietary factors. Zinc, iron, molybdenum, inorganic sulfate and other nutrients can reduce copper absorption (Suttle 2010). FSANZ has established GELs of $50 \mathrm{mg} / \mathrm{kg} \mathrm{WW}$ for edible offal of cattle and pigs and $150 \mathrm{mg} / \mathrm{kg}$ WW for sheep liver that can be used to derive guidance levels for feed (Table 3). A TF of 2.4 has been reported for cattle liver (MacLachlan 2011) suggesting concentrations in cattle feed should not exceed $50 \div 2.4=21 \mathrm{mg} / \mathrm{kg}$ DM. A level of 20 $\mathrm{mg} / \mathrm{kg}$ DM should be adequate to ensure copper concentrations do not exceed $50 \mathrm{mg} / \mathrm{kg} \mathrm{WW}$ in cattle liver. Based on a GEL for sheep liver of $150 \mathrm{mg} / \mathrm{kg} \mathrm{WW}$ and a TF of 5 (MacLachlan 2011), concentrations in the total diet for sheep should not exceed $150 \div$ $5=30 \mathrm{mg} / \mathrm{kg}$ DM. The calculated maximum level for copper in the total diet of sheep is higher than the MTL recommended by the NRC (2005) of $15 \mathrm{mg} / \mathrm{kg}$ DM. As the MTL is lower than the calculated level, the level of copper in the total diet of sheep should not exceed the MTL of $15 \mathrm{mg} / \mathrm{kg}$ DM.

Pigs do not store as much copper in liver as ruminants (Suttle 2010). Based on a GEL of $50 \mathrm{mg} / \mathrm{kg} \mathrm{WW}$ for edible offal of cattle and pigs and a TF of 0.58 for pig liver (MacLachlan 2011), concentrations in the total diet should not exceed $50 \div 0.58=86$ $\mathrm{mg} / \mathrm{kg}$ DM while the calculation for pig muscle suggests copper concentrations in feed should not exceed $133 \mathrm{mg} / \mathrm{kg}$. A level of $100 \mathrm{mg} / \mathrm{kg} \mathrm{DM}$ for the total diet should be adequate to ensure copper in pig tissues do not significantly exceed GEL (90th percentile) levels.

Copper has been incorporated in rations of pigs and poultry at concentrations of up to $50-250 \mathrm{mg} / \mathrm{kg} \mathrm{DM}$ for growth promotion, though in the case of pigs the concentration is usually decreased to $5 \mathrm{mg} / \mathrm{kg}$ DM after the pigs reach $55 \mathrm{~kg}$ liveweight (Jacela et al. 2010). It is noted that the levels in current state regulations take into account use of copper for growth promotion and as such are higher than the guidance maximum levels recommended here.

\section{Fluoride}

Neither MLs nor GELs have been established for fluoride in livestock commodities. It has been reported that the major source of fluorides for grazing livestock in Australia is artesian water supplies, which can contain 1-10 mg fluoride/L. Artesian water has been associated with endemic fluorosis in sheep in localised areas of Queensland (Harvey 1952). The other major source of fluoride is rock phosphates and fertilisers derived from rock phosphates, which are commonly incorporated into stock feeds as phosphate sources. It is to prevent fluorosis in stock from the latter sources, that some states have regulations specifying maximum levels of fluoride in stock feed, which must be observed in these jurisdictions. The limits for fluoride in Queensland (Qld 1997) and Western Australia (WA 2006) are similar. The limits in Queensland for the total diet are $40 \mathrm{mg} / \mathrm{kg}$ for dairy cattle, $150 \mathrm{mg}$ / $\mathrm{kg}$ for breeding pigs, $350 \mathrm{mg} / \mathrm{kg}$ for poultry and $200 \mathrm{mg} / \mathrm{kg}$ for other livestock. Fluoride accumulates in teeth and bone, and concentrations of fluoride in edible tissues are very low (Puls 1994). It is not proposed to recommend levels different to those currently in state regulations.

\section{Lead}

Lead has been a common cause of cattle poisoning in Australia over the last century through use of lead-based paint on stock yards and buildings and through consumption of (apparently sweet-tasting) lead salts derived from discarded sump oil and lead/acid batteries, but these sources are now much better controlled (Burren et al. 2010; Byrne and Gill 2011). Lead impurities are often present in mineral feed materials such as phosphates and oxides, and can contribute significantly to livestock dietary exposure (NRC 2005). Lead is a chronic and cumulative poison and human exposure should be aslow-as-reasonably-achievable (NRC 2005). Lead is absorbed to a different extent depending on various factors (intake, 
Table 4. Current state and recommended guidance maximum levels for various elements in feed $\mathrm{n}$ = New South Wales; $\mathrm{q}=$ Queensland; $\mathrm{w}=$ Western Australia

\begin{tabular}{|c|c|c|c|}
\hline Element, species & Feed & $\begin{array}{c}\text { State maximum } \\
\text { limits }(\mathrm{mg} / \mathrm{kg} \mathrm{DM})\end{array}$ & $\begin{array}{c}\text { Recommended } \\
\text { guidance maximum } \\
\text { level }(\mathrm{mg} / \mathrm{kg} \mathrm{DM})\end{array}$ \\
\hline
\end{tabular}

\section{Antimony}

Cattle, pigs, sheep

Arsenic (total)

Cattle, sheep, pigs

Cadmium

Cattle, poultry, sheep

Pigs

All

All

All

All

All

All

All

All

Chromium

Cattle, pigs, poultry, sheep

Copper

Cattle

Sheep

Pigs

Pigs for breeding

Chickens for meat

Chickens for breeding

Other animals

Cattle, goats, sheep

Fluoride

Dairy cattle, calves

Sheep, pigs (except breeding pigs)

Breeding pigs

Poultry

Cattle (except dairy), goats

Dairy cattle

Cattle (except dairy), goats, sheep

All

Lead

Cattle, pigs, sheep

All

All

All

All

All

All

All

All

All

Mercury

Cattle, pigs, sheep

All

Selenium

Cattle, pigs, sheep

Cattle, goats, sheep

Pigs, poultry
Total diet

Total diet

Total diet

Total diet

Ingredients of vegetable origin

Ingredients of animal origin

Feed additives of mineral origin - phosphates

Feed additives of mineral origin - other than phosphates

Trace element additives based on copper oxide, manganous

oxide, zinc oxide or manganous sulfate monohydrates

Trace element additives - other

Feed additives (binders and anti caking agents)

Premixes

Total diet

Total diet

Total diet

Total diet

Total diet

Total diet

Total diet

Total diet

Stock licks

Stock food

Stock food

Stock food

Stock food

Stock food

Lick or mineral supplement

Lick or mineral supplement

Phosphate for inclusion in manufactured stock food

Total diet

Green fodder

Feed additives based on phosphates

Feed additives based on calcium carbonate

Feed additives based on zeolites of volcanic origin

Feed additives (binders and anti-caking agents except zeolites)

Premixes

Trace element additives based on zinc oxide

Trace element additives based on manganous oxide,

iron carbonate or copper oxide

Trace element additives - other

Total diet

Fish meal

Total diet

Stock food other than licks or mineral supplements

Stock food
0.3

0.2

1

0.5

1

2

20

2

30

10

2

15

20

$20 \mathrm{qw}$

$20 \mathrm{qw}$

20

15

200 q, 220 w except $\quad 100$

breeders

$50 \mathrm{qw}$

$200 \mathrm{q}, 220 \mathrm{w}$

$20 \mathrm{qw}$

$20 \mathrm{qw}$

$1400 \mathrm{qw}$

$40 \mathrm{qw}$

200 qw

$150 \mathrm{qw}$

$350 \mathrm{qw}$

$200 \mathrm{q}$

$400 \mathrm{q}$

$2000 \mathrm{q}$

$40^{\mathrm{B}} \mathrm{w}$

$0.2 \mathrm{nqw}$

$1 \mathrm{w}$

$1 \mathrm{w}$

$1 \mathrm{w}$

$1 \mathrm{w}$

$1 \mathrm{w}$

$1 \mathrm{w}$

$1 \mathrm{w}$

$1 \mathrm{w}$

$1 \mathrm{w}$

$0.02 \mathrm{nqw}$

0.4 nqw

0.01

$-$

0.3

$0.1 \mathrm{q}$

$0.3 \mathrm{q}$

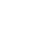

$-$

$-$

$-$

$-$

40

200

150

350

200

400

2000

40

5

30

15

20

60

30

200

400

200

100
3

2

5

.


Table 4. (continued)

\begin{tabular}{|c|c|c|c|}
\hline Element, species & Feed & $\begin{array}{c}\text { State maximum } \\
\text { limits }(\mathrm{mg} / \mathrm{kg} \mathrm{DM})\end{array}$ & $\begin{array}{c}\text { Recommended } \\
\text { guidance maximum } \\
\text { level }(\mathrm{mg} / \mathrm{kg} \mathrm{DM})\end{array}$ \\
\hline Cattle, goats, sheep & Licks & $1 \mathrm{q}$ & - \\
\hline Cattle, goats, sheep & Licks and premixes & $5 \mathrm{w}$ & - \\
\hline \multicolumn{4}{|l|}{ Zinc } \\
\hline Cattle, sheep & Total diet & - & 50 \\
\hline
\end{tabular}

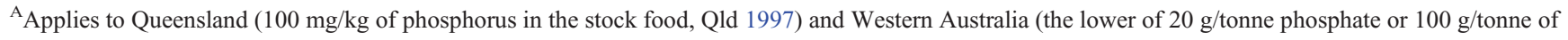
phosphorus in phosphate for inclusion in manufactured stock food, WA 2006).

${ }^{\mathrm{B}}$ Lower of $8 \mathrm{~g} /$ tonne of phosphate or $40 \mathrm{~g} /$ tonne of phosphorus in phosphate (WA 2006).

${ }^{\mathrm{C}}$ Note young pigs can tolerate $3000 \mathrm{mg} / \mathrm{kg}$ (used post-weaning for prevention of diarrhoea).

interaction with other elements, age and species) (Suttle 2010). Concentrations are highest in kidney, liver and bone (NRC 2005).

Data on the lead content of several grains used as feed materials have been reported by the NRS (pers. comm). In most samples lead was not detected above the limit of reporting of $0.01 \mathrm{mg} / \mathrm{kg}$ for cereal grain, pulses and oilseeds. Little data are available publicly on the concentration of lead in premixes and mineral supplements sold in Australia. However, analyses of 100 premixes in the EU showed average lead concentrations of $19 \mathrm{mg} / \mathrm{kg}$ DM (EFSA 2004b). From a database of 198 samples of mineral supplements (EFSA $2004 b$ ), the average concentration was $3.4 \mathrm{mg} / \mathrm{kg}$. Maximum values reported were in two samples of magnesium oxide with concentrations of $30 \mathrm{mg} / \mathrm{kg}$.

Based on the Australian ML of $0.5 \mathrm{mg} / \mathrm{kg}$ WW for edible offal and a TF of 0.12 for cattle kidney (MacLachlan 2011), concentrations in the total diet should not exceed $0.5 \div 0.12=$ $4.2 \mathrm{mg} / \mathrm{kg} \mathrm{DM}$. A level of $5 \mathrm{mg} / \mathrm{kg} \mathrm{DM}$ should be adequate to ensure lead in kidney does not exceed $0.5 \mathrm{mg} / \mathrm{kg} \mathrm{WW}$. Codex has established a ML of $0.02 \mathrm{mg} / \mathrm{kg}$ for milk and using this value together with the TF reported by MacLachlan (2011) concentrations in the total diet of dairy cows should not exceed $0.02 \div 0.0024=8.3 \mathrm{mg} / \mathrm{kg} \mathrm{DM}$. As the level calculated for tissues $(5 \mathrm{mg} / \mathrm{kg} \mathrm{DM})$ is lower than that calculated for milk $(8 \mathrm{mg} / \mathrm{kg} \mathrm{DM})$, concentrations in the total diet should be aslow-as-reasonably-achievable and not greater than $5 \mathrm{mg} / \mathrm{kg}$ DM. Levels of lead in individual feed components should also be as-low-as-reasonably-achievable. Guidance levels for feed ingredients based on the results of the ESFA survey (EFSA 2004b) are summarised in Table 4.

\section{Mercury}

Mercury in the natural environment is found in both inorganic and organic forms (NRC 2005). Sources include some mineral deposits and from inclusion of fish meal in livestock diets (NRC 2005). The inorganic forms of mercury are less toxic than organic ones and among organic forms the most toxic is methyl mercury. Based on the FSANZ GEL of $0.01 \mathrm{mg} / \mathrm{kg} \mathrm{WW}$ for edible offal of cattle, pigs and sheep and a TF of 4.6 for sheep kidney (MacLachlan 2011), concentrations in feed should not exceed $0.01 \div 4.6=0.002 \mathrm{mg} / \mathrm{kg} \mathrm{DM}$. If the calculation is repeated for cattle (GEL $0.01 \mathrm{mg} / \mathrm{kg} \mathrm{WW}$, TF kidney 0.89 ) the concentration in the total diet should not exceed $0.01 \mathrm{mg} / \mathrm{kg}$ DM. A level of $0.01 \mathrm{mg} / \mathrm{kg}$ DM should be adequate to ensure concentrations in kidney of livestock do not significantly exceed $0.01 \mathrm{mg} / \mathrm{kg}$.

The proposed level of $0.01 \mathrm{mg} / \mathrm{kg} \mathrm{DM}$ is lower than in the current state regulations listed in Table 4. Records of the original justification for regulated levels are not available for comparison. The level proposed here is estimated using the FSANZ GEL which in turn is based on the 90th percentile of mercury concentrations reported in surveys of Australian cattle, pig and sheep kidneys. As stated earlier, GELs are not regulatory standards but have been developed to assist food manufacturers in ensuring concentrations of contaminants are as-low-asreasonably-achievable. Higher concentrations in feed may occur if fish meal is included in the ration though it is noted that in this case compliance with the FSANZ 90th percentile GEL might not be possible.

\section{Selenium}

Selenium exposure of livestock can be derived from consumption of selenium-accumulating plants (Neptunia amplexicaulis and Morina reticulata) growing on natural mineral outcrops in parts of Queensland (Tinggi 2003), and from its use as a supplement. The optimum nutritional requirements for selenium are uncertain. FSANZ has established a GEL for selenium concentrations in meat which can be used to derive a guidance level for feed. Based on a GEL of $0.2 \mathrm{mg} / \mathrm{kg} \mathrm{WW}$ for meat of cattle, pigs and sheep and a TF of 0.72 for pig muscle (MacLachlan 2011), concentrations in the total diet should not exceed $0.2 \div 0.72=0.28 \mathrm{mg} / \mathrm{kg}$ DM . A level of $0.3 \mathrm{mg} / \mathrm{kg}$ DM should be adequate to ensure selenium does not exceed the GEL (90th percentile) value reported by FSANZ. Current state regulations are in Table 4. The level proposed for the total diet of $0.3 \mathrm{mg} / \mathrm{kg} \mathrm{DM}$ agrees with the Queensland regulatory level of $0.3 \mathrm{mg} / \mathrm{kg}$ for pig and poultry stock food and is higher than the Queensland limit for cattle, sheep and goat stock food, but lower than the Western Australian level of $1 \mathrm{mg} / \mathrm{kg}$ for manufactured stock food.

\section{Zinc}

Sources of zinc include mineral deposits but are also widespread on farms, due to its use in galvanising metal used in structures 
used in animal husbandry. It is an essential element added to diets of intensively raised livestock (Suttle 2010).

GEL values have been established by FSANZ for zinc in meat and offal and can be used to derive guidance levels for feeds. Based on a GEL (90th percentile) of $60 \mathrm{mg} / \mathrm{kg}$ WW for edible offal of cattle, pigs and sheep and TFs of 1.3 for cattle liver and 0.26 for pig liver (MacLachlan 2011), concentrations in feed should not exceed $60 \div 1.3=46 \mathrm{mg} / \mathrm{kg} \mathrm{DM}$ for cattle and sheep and $60 \div 0.26=230 \mathrm{mg} / \mathrm{kg}$ DM for pigs. Levels of $50 \mathrm{mg} / \mathrm{kg} \mathrm{DM}$ for cattle and sheep and $250 \mathrm{mg} / \mathrm{kg} \mathrm{DM}$ for pigs should be adequate to ensure zinc does not exceed the GEL (90th percentile) proposed by FSANZ.

The guidance maximum levels do not take into account therapeutic use of zinc in the diet. Zinc is sometimes added to the total diet of young pigs post-weaning as a disease preventative at concentrations of up to $3000 \mathrm{mg} / \mathrm{kg}$ DM until a liveweight of $12 \mathrm{~kg}$ is reached (Jacela et al. 2010) and to cattle diets at up to $500 \mathrm{mg} / \mathrm{kg}$ DM for prevention of foot diseases and facial eczema (Dairy Australia 2011).

Both state and proposed guidance maximum levels for various elements are summarised in Table 4. The Supplementary Material (available on the Journal's website) contains a summary of the bioavailability of elements in different matrices relative to the forms used to estimate the transfer from feed to tissues, milk and eggs.

\section{Phytotoxins}

Phytotoxins are defined here as toxic substances naturally produced by plants hence they are regarded as 'natural toxins'. Most have evolved with the plants as defences against insects and other predators, but a small proportion are toxic to livestock (Barry and Blaney 1987), and also present some risk of producing residues in livestock products. Feed ingredients from grain and pulse crops can contain their own respective natural toxins, and can also contain others derived from weeds growing within the crop or at field margins at the time of harvest. Examples of undesirable substances that may be produced as natural components of a crop include gossypol production by cotton (Gossypium spp.) and tetrahydrocannabinol (THC) production by hemp (Cannabis sativa). Fodder crops such as rye grass (Lolium spp.) can also contain simple toxins, like nitrate and oxalate, which can poison livestock but are not persistently residual in livestock products. Advice is freely available to producers to manage the risk of nitrate and oxalate poisoning in grazing livestock, but risks remain for purchased hays and preserved fodder.

\section{Gossypol}

Gossypol in cottonseed meal or oil is transferred to edible tissues including muscle and offal of ruminants and poultry, as well as into eggs and milk (EFSA 2008). Available information on transfer from feed suggests the maximum levels for feed that apply in the EU are adequately protective of livestock and also limit gossypol concentrations in food (EC 2003; EFSA 2008).

\section{Nitrates}

Under normal conditions the nitrate ingested by ruminants is converted to ammonia and then bacterial protein in the rumen
(EFSA 2009). Nitrites are formed as an intermediate in the conversion of nitrate to ammonia. The conversion of nitrates to nitrite occurs at a faster rate than nitrite is converted to ammonia. Consequently, when higher than normal amounts of nitrate are consumed, an accumulation of nitrite may occur in the rumen. Nitrite then will be absorbed into the bloodstream and will convert hemoglobin to methemoglobin, which is unable to transport oxygen, leading to nitrate poisoning (Hill and Blaney 1980; Bruning-Fann and Kaneene 1993). High concentrations of nitrates result in depressed feed intake. Toxic levels of nitrogen in the form of nitrate are above $5000 \mathrm{mg}$ nitrogen $/ \mathrm{kg}$ DM in the diet (EC 1978), although this varies up or down with the condition of the livestock. A guidance level of $2000 \mathrm{mg}$ nitrogen $/ \mathrm{kg} \mathrm{DM}$ $(0.2 \%)$ is proposed, but expressed as the potassium nitrate equivalent of $10000 \mathrm{mg} / \mathrm{kg}(1 \%)$.

\section{Oxalate}

Exposure of livestock to oxalates present in plant material may lead to the precipitation of insoluble calcium oxalate in the kidneys leading to acute renal failure, or in the longer term to calcium deficiency (Blaney et al. 1981, 1982; Rahman et al. 2012). Poisoning in sheep and cattle has been reported when pasture contains $7-8 \%$ soluble oxalate on a DM basis (Seawright et al. 1970; James et al. 1971; James and Butcher 1972) while the presence of $3 \%$ oxalates in the diet of lambs significantly depressed voluntary feed intake (Burritt and Provenza 2000). McKenzie et al. (1988) reported that levels of 2\% or more soluble oxalate (sodium and potassium oxalates, expressed as potassium oxalate equivalent) can lead to acute toxicosis in sheep. A guidance level of $10000 \mathrm{mg}$ soluble oxalates (expressed as potassium oxalate)/kg DM (1\%) should provide a sufficient margin of safety for livestock exposed to feed containing oxalates.

\section{Tetrahydrocannabinol}

THC is the main psycho-active compound found in the leaves and flowering heads of $C$. sativa and is a fat-soluble compound. If hemp products are fed to livestock, THC may transfer to milk and fat. In Queensland, the Stock Regulation 1988 (Qld 1988) imposes restrictions on feeding hemp (C. sativa) to stock. Under the Stock Regulation 1988 (Qld 1988) only low THC containing cannabis products (processed cannabis, oil extracted from processed cannabis and meal ground from processed cannabis) are permitted to be fed to stock. In New South Wales the Stock Foods Regulation 2010 prohibits the inclusion of stock feed of all cannabis plant parts other than seeds which have had the outer bracts removed.

EFSA have recently reviewed available information on the use of industrial (low THC) hemp as a livestock feed and the transfer of THC from hemp to food of animal origin (EFSA 2011). The EFSA Panel on Additives and Products or Substances used in Animal Feed recommended feeds derived from whole hemp plants should be either restricted or prohibited due to the potential for transfer of unacceptable levels of THC and related compounds into food of animal origin. Consistent with the Queensland Stock Regulation, they noted that hemp seed contains lower levels of THC and related compounds compared with whole plants and that hemp seed-derived feed ingredients should not contain more than 
$10 \mathrm{mg}$ THC $/ \mathrm{kg}$ DM when included at a maximum of $20 \%$ of the total diet.

\section{Other plant toxins}

A large number of potentially toxic plants may contaminate pasture and feed (Cheeke 1998). In Australia, Paterson's curse (Echium plantagineum), perennial ryegrass (Lolium perenne), Pimelea spp. and St John's wort (Hypericum perforatum) are a few out of many that are commonly recognised as poisonous plants weeds of importance affecting grazing livestock. An extensive investigation during 2002-08 assessed the risks to human health and trade from the transfer of natural toxin residues from rangeland plants and seeds to foods of animal origin (Blaney et al. 2008a). A comprehensive review of all of the 92 different toxins and toxin groups known to affect animals in Australia and overseas, identified only a very few that were considered as having potential to produce concentrations in foods of animal origin of possible human health significance. These were: pyrrolizidine alkaloids [rattlepods (Crotalaria spp.), heliotropes (Heliotropium spp.), fireweeds (Senecio spp.), Paterson's curse, and others]; indospicine [Birdsville indigo, creeping indigo, etc (Indigofera spp.)]; and ptaquiloside [bracken fern (Pteridium spp.), mulga fern (Cheilanthes spp.)]. Further detailed investigation concluded that the risk to health of persons consuming meat from livestock exposed to pyrrolizidine-containing plants in northern Australia was negligible (Fletcher et al. 2011a). The risks from indospicine in meat and ptaquilosides in milk are not considered high, but are still under investigation (Fletcher et al. 2011b). However, most exposure to the source plants is from grazing situations rather than from contaminated feedstuffs. Consequently, with the current state of knowledge, guidance levels for these natural toxins in feeds are not considered necessary but will be re-assessed as further data become available.

\section{Weed seeds}

Weed seeds can have two potential impacts as contaminants of feed grains. First, toxic components within the seeds, or mechanical irritation caused by seeds such as burrs, can affect livestock health and productivity. Second, the use of weed-contaminated grains in livestock feeds can spread the weed and exacerbate the weed problem. When assessing the consequences of weed seed contamination from a livestock perspective, the biggest consideration is any natural toxin that the weed seed contains. If a weed seed does not contain a toxin, its presence in a grain sample may be of limited concern except for the effect it may have on the ability to define the supply of amino acids and energy that could be expected from the grain sample in question.

A review of Australian weeds (R. A. McKenzie, unpubl. data) identified the following plants as responsible for adversely affecting livestock production when their seeds contaminate feed: Mexican poppy (Argemone mexicana and A. ochroleuca), jute (Corchorus olitorius), rattlepods Crotalaria spp., thornapples (Datura spp.), Paterson's curse (E. plantagineum), common heliotrope (Heliotropium europaeum) and blue heliotrope (H. amplexicauli), bellvine (Ipomoea plebia), darnel (Lolium temulentum), annual yellow sweet clover (Melilotus indicus), climbing buckwheat (Polygonum convolvulus), castor oil plant (Ricinus communis), sesbania pea (Sesbania cannibina), caltrop (Tribulus terrestris), common vetch (Vicia sativa) and burrs (Xanthium spp.). The toxins contained in the seeds include pyrrolizidine alkaloids (rattlepods, Paterson's curse, heliotropes), ricin (castor oil plant), dihydrosanguanarine and dihydrochelerythrine (Mexican poppy) and scopolamine (thornapples). On the basis of plant prevalence, consumption by livestock and persistence of levels in tissues, none of these toxins was considered to present a significant risk of meat contamination except for pyrrolizidine alkaloids and after further investigation that risk is now considered low (Blaney et al. 2008a).

Grain Trade Australia (GTA 2011) nominates weed and foreign seed levels in its purchasing standards with tolerances listed for contamination for a total of 192 weed seeds. Some weed seeds prohibited by state laws against inclusion in stock feeds such as castor oil plant and rattlepods, are listed by GTA as having 'nil' acceptance levels. Others listed above, that are known to be potentially toxic to livestock, are restricted to levels ranging from 2 to 400 seeds/half litre (0.002-0.2\%), according to relative toxicity of the different seeds. Although exact tolerances by different livestock are not known, the restrictions appear to offer a generous safety margin below known toxic levels (Spencer 2010). Sufficient information is not available to estimate guidance levels for most weed seeds. Seed contamination of grain to protect livestock health is best handled through existing GTA receival standards (GTA 2011).

Proposed guidance maximum levels for phytotoxins are summarised in Table 5.

\section{Mycotoxins}

Mycotoxins are 'natural toxins' produced by fungi, which have evolved as defences against predators and competitors, and which are toxic to animals (Blaney 1996). Mycotoxin contamination of forages, cereals and pulse crops frequently occurs in the field following infection of plants with particular pathogenic fungi or with symbiotic endophytes (D'Mello 2004). Production of mycotoxins by fungi can also occur during processing and storage of harvested feed materials when environmental conditions, particularly moisture and ambient temperature are appropriate for development of spoilage fungi (D'Mello 2004). A wide range of mycotoxins affect livestock health in Australia, as in other countries (Bryden 2012a). Most are metabolised fairly quickly after ingestion, and residues do not appear to accumulate or persist in animal products for long periods (Bryden 2009; MacLachlan 2011). Sufficient concerns have been raised regarding aflatoxins in milk and offal, and ochratoxin A in meat and meat products (particularly pork and veal), to warrant regulation in various countries. It should be noted that human exposure to these mycotoxins is predominantly from direct ingestion of contaminated food crops, with exposure from consumption of livestock products relatively minor (Miller 2008; FSANZ 2011).

The 20th Australian Total Diet Survey (FSANZ 2003) investigated the dietary exposure of the Australian population to aflatoxins and ochratoxin A. Aflatoxins (B1, B2, G1 and G2) and ochratoxin A were not found in any food tested, namely: breads, biscuits, rice, oats, processed wheat bran, breakfast 
Table 5. State and recommended guidance maximum levels for phytotoxins in feed

\begin{tabular}{llr}
\hline Phytotoxin & Feed & $\begin{array}{c}\text { Guidance maximum } \\
\text { level (mg/kg DM) }\end{array}$ \\
\hline Gossypol & Total diet adult cattle, goats and sheep & 500 \\
& Total diet calves and poultry other than laying hens & 100 \\
& Total diet for pigs other than piglets & 60 \\
& Total diet for piglets and laying hens & 20 \\
& Cotton seed & 5000 \\
& Cotton seed cakes and meal & 1200 \\
& other feed materials & 20 \\
Nitrates (as potassium nitrate) & Total diet cattle, goats, pigs and sheep & 10000 \\
Oxalates (as potassium oxalate) & Total diet cattle, goats, pigs and sheep & 10000 \\
Tetrahydrocannabinol & Hemp seed-derived feed ingredients & 10 (and max. 20\% \\
& & of the diet) \\
\hline
\end{tabular}

cereals (including infant cereal), instant coffee, peanut butter, almonds and milk chocolate. More recently the 23rd Total Diet Survey (FSANZ 2011) did not detect aflatoxins (B1, B2, G1, G2 and M1), deoxynivalenol (DON), fumonisins (B1 and B2), ochratoxin A, patulin or zearalenone (ZEA) in any food analysed. Mycotoxins other than these have not been considered to be public health concerns at the concentrations so far reported in Australian food crops.

Table 6 lists MLs for food of animal origin for various mycotoxins and includes levels for major markets for Australian livestock commodities.

It is evident that few MLs have been established for mycotoxins in foods of animal origin (Table 6). In many cases the concerns over the presence of mycotoxins in feed relate to their effects on production rather than the safety of animalderived foods (Bryden 2012b). The mycotoxins relevant to livestock production are aflatoxins, ochratoxin A, fumonisins,
ZEA, trichothecenes and ergot alkaloids (Bryden 2012b), while aflatoxins, ochratoxin A and ZEA are also of concern for food of animal origin (see Table 7). In considering guidance levels for mycotoxins, their transfer to animal commodities as well as the effect of feed concentrations on production are considered. The guidance levels proposed here are generally below the lowest adverse effect levels reported in the literature for the various livestock species (Eriksen and Pettersson 2004; Pettersson 2004). It is noted that a few additional mycotoxins relevant to feed have either been detected in Australia, or are likely to occur here based on fungal prevalence, including moniliformin, cyclopiazonic acid, sterigmatocystin, citrinin, alternariols, tenuazonic acid, patulin, etc. Based on current knowledge, these are not considered to present significant risks to either livestock health or to contamination of animal products (B. J. Blaney, unpubl. data), nor are guidance levels considered to be warranted.

Table 6. Maximum limits and action levels ( $\mu \mathrm{g} / \mathrm{kg}$ wet weight) applicable to mycotoxins in meat, meat products and milk in various countries and regions

\begin{tabular}{lccll}
\hline Mycotoxin & $\begin{array}{c}\text { Meat and meat } \\
\text { products }\end{array}$ & Milk & Country/region & Reference \\
\hline Aflatoxin M1 & - & 0.5 & Brazil & Brazil (2011) \\
Aflatoxin M1 & - & 0.05 & Chile & Chile (2011) \\
Aflatoxin M1 & - & 0.5 & China & China (2011) \\
Aflatoxin M1 & - & 0.5 & Codex & Codex (2010) \\
Aflatoxin M1 & - & 0.05 & EU & EC (2006b) \\
Aflatoxin M1 & - & 0.5 & Korea & Korea (2011) \\
Aflatoxin M1 & - & 0.5 & Russia & Russia (2010) \\
Aflatoxin M1 & - & 0.5 & Taiwan & Taiwan $(2009 d)$ \\
Aflatoxin M1 & - & 0.5 & USA & USFDA (2011) \\
Aflatoxin B1 + B2 + G1 + G2 & $30^{\mathrm{A}}$ & - & Brazil & Brazil (2011) \\
Aflatoxin B1 + B2 + G1 + G2 & $5^{\mathrm{A}}$ & - & Chile & Chile (2011) \\
Aflatoxin B1 & $20^{\mathrm{A}}$ & - & USA & USFDA (2011) \\
Aflatoxin B1 + B2 + G1 + G2 & $15^{\mathrm{A}}$ & - & Hong Kong & Hong Kong (2011) \\
$\quad$ M1 + M2 + aflatoxicol & & & & Japan (2011b) \\
Aflatoxin B1 & $\mathrm{ND}^{\mathrm{AB}}$ & - & Japan & FAO (2004) \\
Ochratoxin A & $25(10)$ pork & - & Denmark & Chile (2011) \\
Zearalenone & $200^{\mathrm{A}}$ & - & Chile &
\end{tabular}

${ }^{\mathrm{A}}$ Maximum levels are for all food and would include meat and meat products.

${ }^{\mathrm{B}} \mathrm{ND}=$ no detection permitted, limit of detection for the reference method is $10 \mu \mathrm{g} / \mathrm{kg}$ wet weight.

${ }^{\mathrm{C}}$ Kidney levels: $25 \mu \mathrm{g} / \mathrm{kg}$ condemn pig carcass; $10 \mu \mathrm{g} / \mathrm{kg}$ condemn pig kidney. 
Table 7. Recommended guidance maximum levels for mycotoxins in feed $\mathrm{n}=$ New South Wales; $\mathrm{q}=$ Queensland; $\mathrm{w}=$ Western Australia

\begin{tabular}{|c|c|c|c|}
\hline Mycotoxin & Feed & $\begin{array}{c}\text { State maximum } \\
\text { limit }(\mathrm{mg} / \mathrm{kg} \mathrm{DM})\end{array}$ & $\begin{array}{l}\text { Recommended } \\
\text { guidance maximum } \\
\text { level }(\mathrm{mg} / \mathrm{kg} \mathrm{DM})\end{array}$ \\
\hline \multirow{11}{*}{$\begin{array}{l}\text { Aflatoxins } \\
\qquad(\mathrm{B} 1+\mathrm{B} 2+\mathrm{G} 1+\mathrm{G} 2)\end{array}$} & Ducks & $0.001^{\mathrm{A}} \mathrm{nqw}$ & 0.002 \\
\hline & Layer chickens & $0.02^{\mathrm{A}} \mathrm{nqw}$ & 0.03 \\
\hline & Poultry (other than ducks, layer chickens) & $0.01^{\mathrm{A}} \mathrm{nqw}$ & 0.02 \\
\hline & Weaner pigs & $0.01^{\mathrm{A}}$ nqw & 0.02 \\
\hline & Grower pigs, finisher pigs & $0.05^{\mathrm{A}} \mathrm{nqw}$ & 0.08 \\
\hline & Beef cattle, sheep & $0.05^{\mathrm{A}} \mathrm{nqw}$ & 0.08 \\
\hline & Dairy cows, dairy sheep, dairy goats & $0.02^{\mathrm{A}} \mathrm{nqw}$ & 0.03 \\
\hline & Feed ingredients & & - \\
\hline & Cotton seed, peanut meal, peanut screenings & $0.2^{\mathrm{A}} \mathrm{nw}$ & - \\
\hline & $\begin{array}{l}\text { Meal of canola, coconut, linseed, lupin, pea, } \\
\text { safflower, soybean and sunflower }\end{array}$ & $0.1^{\mathrm{A}} \mathrm{nw}$ & - \\
\hline & Grain, crushed & $0.01^{\mathrm{A}} \mathrm{nw}$ & - \\
\hline \multirow[t]{4}{*}{ Ochratoxin A } & Calves, kids, lambs, weaner pigs & - & 0.05 \\
\hline & Pigs (other than weaner pigs) & - & 0.1 \\
\hline & Poultry & - & 0.1 \\
\hline & Cattle, sheep, goats & - & 0.2 \\
\hline \multirow{7}{*}{$\begin{array}{l}\text { Fumonisins } \\
\qquad(\mathrm{B} 1+\mathrm{B} 2+\mathrm{B} 3)\end{array}$} & Weaner pigs & - & 5 \\
\hline & Grower pigs, finisher pigs & - & 10 \\
\hline & Calves, kids, lambs & - & 10 \\
\hline & Layer and breeder poultry & - & 15 \\
\hline & Dairy and breeding cattle, sheep, goats & - & 15 \\
\hline & Meat chickens, turkeys, ducks & - & 30 \\
\hline & Cattle, sheep, goats & - & 30 \\
\hline \multirow[t]{6}{*}{ Zearalenone } & Breeding sows, weaner pigs & - & 0.05 \\
\hline & Dairy and breeding cattle, sheep, goats & - & 0.2 \\
\hline & Calves, kids, lambs & - & 0.5 \\
\hline & Grower pigs, finisher pigs & - & 2 \\
\hline & Non-breeding cattle, sheep, goats & - & 2 \\
\hline & Poultry & - & 2 \\
\hline \multirow{4}{*}{$\begin{array}{l}\text { Deoxynivalenol + nivalenol } \\
\text { (deoxynivalenol + nivalenol } \\
+ \text { their acetyl derivatives) }\end{array}$} & Pigs & - & 0.5 \\
\hline & Calves, kids, lambs & - & 1 \\
\hline & Cattle, sheep, goats, other than young animals & - & 2 \\
\hline & Poultry & - & 2 \\
\hline \multirow[t]{4}{*}{$\begin{array}{l}\text { Rye ergots (rye ergot }{ }^{B} \text { or total rye ergot } \\
\text { alkaloids }{ }^{\mathrm{C}} \text { in the total diet) }\end{array}$} & Cattle, sheep, goats & $200(0.02 \%)$ as ergot qw & $\begin{array}{l}100(0.01 \%) \text { as ergot or } \\
0.2 \mathrm{mg} \text { alkaloids } / \mathrm{kg} \mathrm{DM}\end{array}$ \\
\hline & Weaner pigs, breeder pigs & $200(0.02 \%)$ as ergot qw & $\begin{array}{l}200(0.02 \%) \text { as ergot or } \\
0.4 \mathrm{mg} \text { alkaloids } / \mathrm{kg} \mathrm{DM}\end{array}$ \\
\hline & Grower pigs, finisher pigs & $200(0.02 \%)$ as ergot qw & $\begin{array}{l}1000(0.1 \%) \text { as ergot or } \\
2 \mathrm{mg} \text { alkaloids/kg DM }\end{array}$ \\
\hline & Poultry & $200(0.02 \%)$ as ergot qw & $\begin{array}{l}2000(0.2 \%) \text { as ergot or } \\
4 \mathrm{mg} \text { alkaloids/kg DM }\end{array}$ \\
\hline Ergot other than sorghum ergot & All species & $200(0.02 \%)$ as ergot qw & - \\
\hline \multirow[t]{6}{*}{$\begin{array}{l}\text { Sorghum ergot (sorghum ergot }{ }^{\mathrm{D}} \text { or total } \\
\text { sorghum ergot alkaloids }{ }^{\mathrm{E}} \text { in the total diet) }\end{array}$} & Dairy and breeding cattle, goats, sheep & - & $\begin{array}{l}300(0.03 \%) \text { as ergot or } \\
0.1 \mathrm{mg} \text { alkaloids } / \mathrm{kg} \mathrm{DM}\end{array}$ \\
\hline & Non-breeding cattle, sheep, goats & - & $\begin{array}{l}1000(0.1 \%) \text { as ergot or } \\
0.3 \mathrm{mg} \text { alkaloids } / \mathrm{kg} \mathrm{DM}\end{array}$ \\
\hline & Weaner pigs, breeder pigs & - & $\begin{array}{l}1000(0.1 \%) \text { as ergot or } \\
0.3 \mathrm{mg} \text { alkaloids } / \mathrm{kg} \mathrm{DM}\end{array}$ \\
\hline & Grower pigs, finisher pigs & - & $\begin{array}{l}10000(1 \%) \text { as ergot or } \\
3 \mathrm{mg} \text { alkaloids/kg DM }\end{array}$ \\
\hline & Poultry & - & $\begin{array}{l}20000(2 \%) \text { as ergot or } \\
6 \mathrm{mg} \text { alkaloids/kg DM }\end{array}$ \\
\hline & All species & $3000(0.3 \%)$ as ergot qw & - \\
\hline
\end{tabular}

\footnotetext{
${ }^{\mathrm{A}}$ Aflatoxin B1 only. ${ }^{\mathrm{B}}$ The sclerotia of Claviceps purpurea. $\quad{ }^{\mathrm{C}}$ The total of ergotamine, ergocryptine, ergosine, ergocornine, ergocristine and their respective C8 epimers, ergotaminine, ergocryptinine, ergosinine, ergocorninine and ergocristinine; or if only ergotamine is measured, $3 \times$ ergotamine. ${ }^{\mathrm{D}}$ Sorghum ergot, Claviceps africana, is defined as the total weight of all ergot bodies, including mature sclerotia, sphacelia with glumes attached, and sphacelia overgrown with sporodochia of the ergot saprophyte Cerebella spp. ${ }^{\mathrm{E}}$ The total of dihydroergosine, dihydroelymoclavine and festuclavine or if only dihydroergosine is measured, $1.2 \times$ dihydroergosine.
} 
Strategies to mitigate the effect of mycotoxin contamination of feed and the effects on livestock production exist (Jard et al. 2011). Feed can be subject to decontamination treatments or the mycotoxin detoxified. The most common approaches reported are the inclusion of sorbent materials in the feed to reduce the amount of toxin absorbed from the gastrointestinal tract and the use of de-toxifying enzymes or microorganisms (Jard et al. 2011). The effectiveness of treatments in practical situations has not always been adequately demonstrated (Kolossova et al. 2009). The guidance levels proposed here (Table 7) assume mitigating treatments have not been employed before use of contaminated feed.

\section{Aflatoxins}

Aflatoxins are a group of chemically similar compounds produced mainly by Aspergillus flavus and A. parasiticus. The principal aflatoxins are B1, B2, G1 and G2. All four aflatoxins can contaminate livestock feed though B1 is the most toxic. Feeds most susceptible to aflatoxin are summer cereals (especially maize), cottonseed, peanuts and copra meal.

Aflatoxins are best known in Australia as a problem in rain-fed (non-irrigated) peanuts grown in parts of the Burnett region in south-east Queensland (Graham 1982; Blaney 1985; Rachaputi et al. 2002), but are also a problem in maize for similar reasons. A. flavus is able to grow in peanuts and maize of lower moisture content and at higher temperatures than many other fungi found on field crops. In healthy peanuts and maize, plant defences prevent growth of Aspergillus spp., but when low available moisture and high temperatures affect kernel development, plant defences are lowered and these fungi can invade. Maize is the only grain crop where aflatoxins are known to cause serious pre-harvest contamination. Significant concentrations of aflatoxins have not been detected in wheat and barley (or grain sorghum) without a history of storage problems. Cottonseed, other oilseeds and nuts like pistachios appear to have minor contamination problems in Australia compared with elsewhere. Low concentrations might occasionally be detected in mouldy hay and straw, but generally $A$. flavus and $A$. parasiticus are not competitive with other fungi on these high-cellulose materials.

There are reports of livestock being affected by aflatoxins in Australia including chickens (Gardiner and Oldroyd 1965), turkeys (Hart 1965), ducks (Bryden et al. 1980), pigs (Ketterer et al. 1982) and cattle (McKenzie et al. 1981). The sources of aflatoxin in these cases included peanut meals and by-products, mouldy bread and other bakery waste, and grain sorghum and maize that were stored with high moisture contents.

Although Queensland (Qld 1997) has regulated aflatoxins in feed for many years to protect animal health, the need for this is under review, particularly as the peanut and maize industries (those with most aflatoxin problems), have a long history of responsible mycotoxin management in their stock feeds and by-products. Nevertheless, there remains strong justification for regulating aflatoxin concentrations in feed to minimise resultant milk contamination. Aflatoxin B1 is converted to aflatoxin $\mathrm{M} 1$ in the mammalian liver and $\sim 1-6 \%$ of aflatoxin B1 ingested by lactating animals is transmitted into milk as aflatoxin M1. The USA has a limit of $0.5 \mu \mathrm{g} / \mathrm{L}$ (USFDA 2011) for aflatoxin M1 in milk while the EU has a limit of $0.05 \mu \mathrm{g} / \mathrm{L}$ (EC $2006 b$ ). The EU limit of $0.05 \mu \mathrm{g} / \mathrm{L}$ is not consistent with widely applied feed limits, including its own limit of $0.02 \mathrm{mg} / \mathrm{kg}$ (EFSA $2004 c$ ). For example, based on an ML of $0.05 \mu \mathrm{g} / \mathrm{L}$ for milk and a TF of 0.015 for cattle milk (MacLachlan 2011), levels of aflatoxin B1 in the total diet of dairy cattle should not exceed $0.00005 \div$ $0.015=0.0033 \mathrm{mg} / \mathrm{kg}$ DM. If bulking and blending of milk from individual cows occurs before use a greater level in feed could be accommodated. Some countries have established MLs for food in general and based on an ML of $5 \mu \mathrm{g} / \mathrm{kg} \mathrm{WW}$ for food (includes meat and meat products) in Chile together with a TF of 0.0025 for cattle liver (MacLachlan 2011), levels of aflatoxin B1 in the total diet of beef cattle should not exceed $0.005 \div 0.0025=2 \mathrm{mg} / \mathrm{kg}$ DM. However, this would be a toxic concentration for beef cattle, which can tolerate only $0.1-0.3 \mathrm{mg} / \mathrm{kg}$ DM over a short term. We therefore recommend a guidance limit of $0.08 \mathrm{mg} / \mathrm{kg} \mathrm{DM}$, which, using the TF of 0.0025 for alfatoxin B1 and assuming the TF also applies to the sum of aflatoxins B1 $+\mathrm{B} 2+\mathrm{G} 1+\mathrm{G} 2$, could produce a maximum aflatoxin concentration of $0.2 \mu \mathrm{g} / \mathrm{kg}$ in liver.

Aflatoxins are carcinogens and residues in food should be as-low-as-reasonably-achievable (IARC 1993). There is no evidence that the current Australian maximum levels in state legislation for feed are inappropriate. Concentrations of aflatoxin in feed should not be higher than permitted by existing standards. To enable comparison with those standards specified in terms of the sum of aflatoxins B1 + B2 + G1 + G2 rather than aflatoxin B1, existing standards in the Queensland regulations (Q1d 1997) have been converted into the most likely equivalent concentrations of total aflatoxins B1 + B2 + G1 + G2 in feeds, total aflatoxins $=1.6 \times$ aflatoxin B1 (Weidenbörner 2001). Although chickens, adult ruminants and finisher pigs may tolerate much higher concentrations $(0.1-0.3 \mathrm{mg} / \mathrm{kg} \mathrm{DM})$ for short periods, it is considered that the Australian grain and feed industries can meet the lower levels with good agricultural practice. The maize industry has set its own limit of $0.08 \mathrm{mg} /$ $\mathrm{kg}$ DM for Feed No. 2 grade. Guidance maximum levels for total aflatoxins B1 + B2 + G1 + G2 in the total diet are listed in Table 7 .

\section{Ochratoxin A}

Ochratoxin A is produced by Aspergillus ochraceus, A. carbonarius, A. niger and Penicillium verrucosum (Pitt et al. 2000). Ochratoxin contamination has been identified in grapes and grape products in Australia, mainly due to A. carbonarius (Hocking et al. 2003), and is known as a contaminant of coffee beans and figs elsewhere. Growth of $P$. verrucosum in storage has caused serious ochratoxin contamination of barley and other grains in Canada and Europe, but it is generally not found in NRS surveys of Australian small grains (NRS, unpubl. data) nor during screening of several hundred 'fair average quality' sorghum samples from Queensland (B. J. Blaney, unpubl. data). Ochratoxin A has been detected on rare occasions and in very low concentrations $(0.001-0.004 \mathrm{mg} / \mathrm{kg})$ in maize at harvest in Australia however, most surveys of Australian maize have not detected any ochratoxin A (Blaney et al. 1984b, 1986; Bricknell et al. 2008; R. Maryam and B. J. Blaney, unpubl. data). There have been no proven cases of ochratoxin poisoning of cattle, goats, sheep, pigs or poultry in Australia. 
In ruminants, ochratoxin $\mathrm{A}$ is degraded by rumen protozoa and bacteria to the less toxic ochratoxin- $\alpha$ with negligible transfer of ochratoxin A to tissues and milk (Müller et al. 1998). Ochratoxin $\mathrm{A}$ is widely distributed in monogastric species such as pigs and chickens with highest concentrations observed in kidney and liver. Denmark has implemented a management system for pigs where kidneys with concentrations above $0.01 \mathrm{mg} / \mathrm{kg} \mathrm{WW}$ are discarded. The TF estimated by MacLachlan (2011) was 0.11 for kidney and ochratoxin $\mathrm{A}$ in the total diet for pigs should not exceed $0.01 \mathrm{mg} / \mathrm{kg} \div 0.11=0.1 \mathrm{mg} / \mathrm{kg}$ DM to meet the management level implemented in Denmark.

Currently, there are no regulations for ochratoxin $\mathrm{A}$ in Australia and all indications are that it does not present a significant risk to human health or livestock in Australia. The very low contamination in Australian feed does not justify any specific restriction on feed nor regulatory levels for food of animal origin to protect human health. Guidance for animal feed could be justified in light of the need to address concentrations that might occur in imported feed, feed ingredients and feed additives. Additionally, the increasing scrutiny of feed materials using increasingly sensitive assay methods is likely to lead to more detection, which will raise problems in interpreting risk to livestock unless levels are available to interpret their significance.

Pigs have been found to be the food-producing animals most sensitive to ochratoxin A. Microscopic lesions were detected in the kidney of female pigs fed $1 \mathrm{mg} / \mathrm{kg}$ feed for 2 years (KuiperGoodman and Grant 2007) and reduced growth rates reported for pigs fed 0.2-2 mg/kg feed (Madsen et al. 1982a, 1982b; Tapia and Seawright 1984). Ruminants are less sensitive due to conversion of ochratoxin A to ochratoxin- $\alpha$ in the rumen and levels in the total diet of $0.2 \mathrm{mg} / \mathrm{kg} \mathrm{DM}$ for ruminants and $0.1 \mathrm{mg} / \mathrm{kg} \mathrm{DM}$ for adult pigs should be adequately protective. A concentration of $1 \mathrm{mg} / \mathrm{kg}$ has been shown to produce minor kidney damage in long-term feeding studies with young pigs, so $0.05 \mathrm{mg} / \mathrm{kg} \mathrm{DM}$ in the total diet would appear to offer a generous safety margin when applied to young pigs and pre-ruminant animals (calves, kids and lambs). Australian broiler chickens (3 weeks of age) fed $1 \mathrm{mg} / \mathrm{kg}$ for 5 weeks were not adversely affected (Reichmann et al. 1982). Other studies have reported reduced growth and also reduced egg production in chickens exposed to $0.5-1 \mathrm{mg} / \mathrm{kg}$ feed (Huff et al. 1975; Krogh et al. 1976; Prior and Sisodia 1978; Page et al. 1980). A guidance level of $0.1 \mathrm{mg} / \mathrm{kg} \mathrm{DM}$ is suggested for poultry. Guidance maximum levels for ochratoxin $\mathrm{A}$ in the total diet are proposed and listed in Table 7 . The suggested levels have substantial safety margins in relation to known no observable effect levels for livestock reviewed by EFSA (2004d), but available survey data suggest that meeting these levels should have minimal impact on Australian feed producers and are consistent with the as-low-as-reasonably-achievable principle.

\section{Fumonisins}

Fumonisins are a group of chemically related polar compounds based on a hydroxylated hydrocarbon chain with methyl and amino (or acetyl) substituents (CAST 2003). The most common and toxic is fumonisin B1, with B2 and B3 usually accompanying B1 but in much lower concentrations (Marasas 1996). Fumonisins appear predominantly to occur in maize, being produced by several Fusarium spp. that are associated with ear rot and stalk rot in maize worldwide with some reports also in sorghum (Munkvold and Desjardins 1997; Leslie and Marasas 2001). The most common species is Fusarium verticillioides (previously called F. moniliforme, Seifert et al. 2003), which appears to be the main source of fumonisins (Munkvold and Desjardins 1997). Fumonisins are present in maize in all Australian growing regions and concentrate in lightweight grain screenings (Bricknell et al. 2008).

In Queensland, the significance of kernel-rot varies between seasons. For example, it was severe on the southern Downs in 1985-86 (Williams et al. 1992) and some concentrated samples of damaged kernels obtained during 1985-86 were later found to contain up to $40 \mathrm{mg}$ fumonisins $/ \mathrm{kg}$ (B. J. Blaney, unpubl. data). In 2003, maize grown in the Murrumbidgee Irrigation Area of southern New South Wales had an increase in kernel-rot, and several samples contained 5-50 mg fumonisins $/ \mathrm{kg}$ (Blaney et al. $2008 b$ ). However, concentrations of fumonisins in maize from surveys conducted of Australian maize-growing regions in $2004-06$ were $>0.1 \mathrm{mg} / \mathrm{kg}$ in $66 \%$ of samples with over $85 \%$ of all samples complying with the GTA standard for milling grade maize ( $2 \mathrm{mg} / \mathrm{kg})$ (Bricknell et al. 2008). Only 2 of 567 samples exceeded the GTA grade 2 feed standard (40 mg/kg).

Fumonisins are not currently regulated by governments in Australia. The GTA trading standards set by the maize industry for the sum of fumonisins B1 + B2 + B3 are $10 \mathrm{mg} / \mathrm{kg}$ for GTA grade 1 feed and $40 \mathrm{mg} / \mathrm{kg}$ for GTA grade 2 feed and are consistent with overseas proposals (USFDA 2001a, 2001b). The risks for livestock appear low given that maize is rarely the main grain component of mixed diets in Australia.

Studies on the carry-over of fumonisins from feed into animal products all indicated that low concentrations of fumonisin B1 can be detected in various tissues, but the low rate of transfer suggests animal products do not contribute substantially to human exposure (EFSA 2005a; MacLachlan 2011).

In animals, fumonisins (particularly B1) are known to cause a wide range of illnesses such as leucoencephalomalacia in horses (Shanks et al. 1995) and pulmonary oedema in pigs. The experimental oral dose leading to porcine pulmonary oedema after less than 5 days exposure is $20 \mathrm{mg} / \mathrm{kg}$ bodyweight per day (Gumprecht et al. 2001), while a dose of $0.4 \mathrm{mg} / \mathrm{kg}$ bodyweight per day was sufficient to cause mild cases in piglets when fed to pigs for a period of 4 weeks (Zomborszky et al. 2000).

The guidance levels listed in Table 7 are consistent with the United States Food and Drug Administration (USFDA 2001b) guidelines and also in harmony with the maize industry standards for feed grade maize once maize is formulated into complete diets (GTA 2011).

\section{Zearalenone}

ZEA is a substituted resorcyclic acid lactone. It is a non-steroidal estrogenic mycotoxin that has been implicated in some forms of infertility in pigs, cattle, sheep and possibly other animals. It has not been proven to affect human health (EFSA 2004e).

In maize, wheat, barley and triticale, ZEA is primarily produced by $F$. graminearum, a fungus responsible for causing ear and stalk rots of maize and head scab (head blight) of small grains (Burgess et al. 1981). Other species known to 
produce ZEA in grain include $F$. culmorum, $F$. equiseti and $F$. crookwellense, while $F$. pseudograminearum is a major source in wheat and barley crowns and stalks.

In maize, significant concentrations of ZEA can be most frequently detected on the tablelands of Far North Queensland where the persistently wet climate favours ear rot by $F$. graminearum and concentrations of $\sim 1 \mathrm{mg} / \mathrm{kg}$ can be quite common (Blaney et al. 1984b, 1986). The most contaminated kernels can be distinguished by a dark purplish colouration. Samples with $2 \%$ of purple kernels contained $\sim 1 \mathrm{mg} \mathrm{ZEA} / \mathrm{kg}$. Continued breeding of maize hybrids for resistance to ear rot appears to have decreased ZEA concentrations over the last 20 years. Another area where $F$. graminearum is relatively common in maize is in the wet coastal districts of south-east Queensland and northern New South Wales. ZEA contamination in these zones is related to the presence of inoculum but incidence is determined by timing of rainfall in relation to silking and the relative resistance of the maize hybrids planted. In wheat, barley and triticale, head blight caused by $F$. graminearum and $F$. culmorum occurs at quite low prevalence, even in wetter regions of Australia where maize (and sorghum) is also grown. A survey of all wheat grown in south-east Queensland in 1983-85 by Blaney et al. (1987) reported a maximum level of $0.04 \mathrm{mg} / \mathrm{kg}$ in bulk wheat with a maximum of $0.43 \mathrm{mg} / \mathrm{kg}$ in an individual wheat delivery to a storage facility.

Factors favouring $F$. graminearum infection are the key to the difference in prevalence of ZEA in maize compared with the small grains. $F$. graminearum causes head blight of wheat, and rotating wheat and maize is a common cause of increased infection in both crops if climatic factors suit (Blaney et al. 1987; Southwell et al. 2003). Head blight is occasionally detected in other areas of Australia when there are unusually wet springs. Because of climate and limited production of maize in wheat-growing regions, it can be concluded that the risk of ZEA contamination of wheat grain is low in Australia. In contrast, the risk of ZEA contamination of hay prepared from wheat and barley stalks is high. F. pseudograminearum is the cause of crown rot of wheat and barley in Australia, one of the most serious diseases of wheat in the northern wheat-growing regions. This fungus produces very high ZEA concentrations $(20-40 \mathrm{mg} / \mathrm{kg})$ in the crowns and stalks of infected plants (Blaney et al. 1987). ZEA is also a common contaminant of weather-damaged sorghum grain in Queensland, though usually at low concentrations. Storage of weather-damaged sorghum in moist, cool conditions can allow high concentrations to develop. There is a growing body of evidence that Fusarium species capable of ZEA production are also widespread in Australian pastures (Reed and Moore 2009).

There is only limited transmission of ZEA and its oestrogenic metabolites into tissues, milk and eggs (MacLachlan 2011). EFSA (2004e) concluded that due to rapid biotransformation and excretion of ZEA in animals, that secondary human exposure from residues in milk, meat and eggs was expected to be low and contribute only marginally to the daily intake. Chile has established an ML for food, and based on the ML of $200 \mu \mathrm{g} /$ $\mathrm{kg}$ for food in Chile and a TF of 0.021 for muscle of pigs (MacLachlan 2011), levels in the total diet should not exceed $0.2 \div 0.021=9.5 \mathrm{mg} / \mathrm{kg}$ DM. Animal production considerations require lower levels in feed.
A concentration of $8 \mathrm{mg} / \mathrm{kg}$ ZEA was detected in sorghum grain used as feed and associated with oestrogenic effects in pigs on the Atherton Tableland (Blaney et al. 1984a). Young female pigs appear to be the most susceptible class of animal to ZEA, where oestrogenic effects can be produced at concentrations of $0.2 \mathrm{mg} / \mathrm{kg}$ in the total diet although these effects are more consistent at $1 \mathrm{mg} / \mathrm{kg}$ (Williams et al. 1988; Williams and Blaney 1994). In some field cases, effects are associated with even lower concentrations $(0.1 \mathrm{mg} / \mathrm{kg})$ and it appears that once young pigs have ingested sufficient ZEA to induce pseudo-oestrogenism that lower concentrations can maintain that condition (Biehl et al. 1993). Guidance levels of $0.05 \mathrm{mg} / \mathrm{kg}$ DM are proposed for young pigs and also breeding sows.

Ewes are also sensitive to ZEA (Smith and Morris 2006). Studies by Smith et al. (1990) showed that doses of ZEA equivalent to dietary concentrations of $\sim 1 \mathrm{mg} / \mathrm{kg}$ administered from Day 7 of oestrus until mating reduced ovulation rate, increased duration of oestrus and increased uterine weight. Higher concentrations reduced incidence of ovulation and reduced fertilisation. ZEA given several days after mating did not produce adverse effects (Smith et al. 1990).

New Zealand pasture samples associated with reduced ewe fertility have been recorded as containing $0.2-2.6 \mathrm{mg} / \mathrm{kg} \mathrm{DM}$ (di Menna et al. 1985). The susceptibility of young heifer cattle has not been adequately explored but a similar tolerance as ewes might be expected. In New Zealand, reproductive problems in dairy cattle have been associated with dietary concentrations of $\sim 0.4 \mathrm{mg} / \mathrm{kg}$ (Towers et al. 1995). Guidance levels of $0.2 \mathrm{mg} / \mathrm{kg}$ $\mathrm{DM}$ are proposed for dairy and breeding ruminants and $0.5 \mathrm{mg} / \mathrm{kg}$ DM for young ruminants. Non-breeding cattle, goats, sheep and pigs can tolerate much higher concentrations and a guidance level of $2 \mathrm{mg} / \mathrm{kg} \mathrm{DM}$ is proposed for these animals.

Poultry are quite resistant to ZEA and concentrations ranging from 10 to $800 \mathrm{mg} / \mathrm{kg}$ have been required to produce significant effects (Chi et al. 1980a, 1980b; Allen et al. 1981 a, 1981b; Olsen et al. 1986; Maryamma et al. 1992). A guidance level of $2 \mathrm{mg} / \mathrm{kg}$ DM would offer a considerable safety margin.

Fortunately the low prevalence of ZEA contamination in Australian feeds, with the notable exception of wheaten/barley hays and possibly pasture hays, allows a safety margin to be used in proposing guidance levels. The guidance levels listed in Table 7 allow for individual feed ingredients such as maize to contain $0.1-2 \mathrm{mg} / \mathrm{kg}$ DM and on current information $>99.9 \%$ of Australian maize would meet this standard.

\section{Trichothecenes}

DON and nivalenol (NIV) are trichothecenes, a large group of sesquiterpenes that are broadly divided into Type A (T-2 toxin; HT-2 toxin, diacetoxyscipenol, etc), Type B (DON, NIV) and macrocyclic trichothecenes (verrucarins, roridins). Acute exposure to trichothecenes induces anorexia at low doses and emetic effects at higher doses as well as causing problems with cell replication, irritation of the gastrointestinal tract and effects on the immune system. Type A trichothecenes including T-2 toxin produced by $F$. sporotrichioides and $F$. poea in millet have been associated with the human disease alimentary toxic aleukia that was first reported in Russia in the 19th century (Ueno 1983). Cold, moist grain storage appears to favour growth of these fungi. 
Fusarium with the potential to produce Type A trichothecenes such as $F$. equiseti, $F$. semitectum, $F$. acuminatum have been isolated from maize and maize soils in Australia (Wearing and Burgess 1978; Watson et al. 2006) but their relatively low prevalence in maize suggests that the risk of contamination with type A trichothecenes is also low and probably confined to cooler and wetter districts. Poisoning of livestock by type A trichothecenes has not been diagnosed in Australia and problems with livestock production (vomiting and reduced feed intake, particularly by pigs) are also uncommon (Moore et al. 1985; Tobin 1988). On the other hand, type B trichothecenes tend to be produced by Fusarium spp., such as $F$. graminearum and $F$. culmorum, that favour warm to temperate climates that occur in parts of Australia.

F. graminearum has a wide distribution in Australian grain crops in warmer regions, causing stalk and ear rots of maize, while a closely related fungus $F$. pseudograminearum causes crown rot of wheat, barley and triticale, but rarely affects the grain (Francis and Burgess 1977). F. culmorum is more common on wheat than maize and prefers cooler latitudes in Australia (Burgess et al. 1981). There are two different 'chemotypes' of F. graminearum; those producing predominantly DON and its acetylated derivatives, and those that produce predominantly NIV and its acetylated derivatives (Ichinoe et al. 1983). Both chemotypes occur in wheat, barley and sorghum in southern Queensland and northern New South Wales but DON producers predominate, whereas only NIV producers have been found on maize in Far North Queensland where wheat is not grown (Blaney and Dodman 1988, 2002). Both chemotypes also produce ZEA. F. pseudograminearum and F. culmorum also produce DON and ZEA.

Infection of maize by $F$. graminearum is favoured by warm, wet conditions during flowering and persistently wet weather during maturation, which are common in Australia only in wetter localities on the tablelands of Far North Queensland and the north coast of New South Wales. Infection of wheat, barley and triticale is also associated with warm, wet conditions during flowering, but particularly in crop rotation with maize and perhaps sorghum. Except in the small localities mentioned, these conditions are also unusual in Australia and infections are associated with unusually wet springs combined with transient increases in maize cropping.

As with ZEA, monitoring of pink-purple discoloured kernels in grain is a useful screening test. In samples collected in the worst affected regions of the northern tablelands in Queensland in 1983 and 1984, the average concentration of NIV in samples with $<0.25 \%$ purple kernels was $0.13 \mathrm{mg} / \mathrm{kg}$, in samples with $0.25-1 \%$ purple kernels $0.66 \mathrm{mg} \mathrm{NIV} / \mathrm{kg}$, and in samples with $>1 \%$ purple kernels $1.21 \mathrm{mg} \mathrm{NIV} / \mathrm{kg}$ with the maximum of $2.5 \mathrm{mg} \mathrm{NIV} / \mathrm{kg}$ detected in a sample with $>2 \%$ of purple kernels (B. J. Blaney, unpubl. data). Continued breeding of maize hybrids for resistance to ear rot in the 20 years since those surveys has probably reduced the extent of contamination.

In wheat, barley and triticale, head blight occurs at quite low prevalence in wetter regions where maize (and sorghum) is also grown. Blaney et al. (1987) reported results of a survey of wheat grown in south-east Queensland in 1983-85 including all regions where head blight is significant and in a year where rainfall had been unusually high. Sixty-two of 1291 wheat delivery samples showed physical evidence of head blight (bleached, shrunken grain, some with dark pink tips). Samples pooled according to receipt depot and grade had low concentrations of DON $(<0.12$ $\mathrm{mg} / \mathrm{kg}$ ) with the exception of one pooled sample that contained $1.7 \mathrm{mg} / \mathrm{kg}$. The Australian Wheat Board has conducted surveys since 1995, which confirm the overall pattern of low prevalence of DON in small grain with detections predominantly confined to certain localities in seasons with unusually wet springs. Human exposure to the type B trichothecenes DON and NIV from wheat is not significant in Australia (Tobin 1988; Webley and Jackson 1998).

In the USA $1 \mathrm{mg} / \mathrm{kg}$ DM is the most stringent advisory level for DON in finished wheat products (USFDA 2010). Grain and grain by-products for ruminating cattle and chickens are allowed $10 \mathrm{mg}$ $\mathrm{DON} / \mathrm{kg}$ DM provided they supply no more than $50 \%$ of the total $\operatorname{diet}(5 \mathrm{mg} / \mathrm{kg}$ DM in the total diet). Grain and by-products for pigs are allowed $5 \mathrm{mg} \mathrm{DON} / \mathrm{kg}$ DM provided they supply no more than $20 \%$ of the total diet $(1 \mathrm{mg} / \mathrm{kg} \mathrm{DM}$ in total diet). For all other animals, grain and by-products can contain $5 \mathrm{mg}$ DON $/ \mathrm{kg}$ DMbut not exceed $40 \%$ of the total diet $(2.5 \mathrm{mg} / \mathrm{kg} \mathrm{DM}$ in the total diet) (Park and Troxell 2002).

There are no current regulations or standards applicable for DON or NIV in Australian grain except for tolerances of 'nil' pink grains in industry grain receival standards. The GTA standard for all maize grades currently contains a 'nil' tolerance for Fusarium (pink) fungal-stained grain (GTA 2011). Regular testing of maize for DON and NIV does not appear to be warranted except in maize grown in areas of known risk, and checking for pink/purple grain in the first instance will further reduce the risks.

The potential for residues in animal products has been reviewed (EFSA 2004f; MacLachlan 2011). DON is well absorbed and metabolised into less toxic products. Elimination occurs by renal and biliary excretion and only trace amounts are transferred into tissues, milk and eggs.

Several studies in North America have indicated that feed naturally contaminated with DON has more impact than when pure DON is administered to animals (Forsyth et al. 1977; Foster et al. 1986; Rotter et al. 1994; Trenholm et al. 1994). In pigs a temporary reduction in feed intake was observed at $0.35 \mathrm{mg}$ $\mathrm{DON} / \mathrm{kg}$ feed but no lasting effect has been shown at $0.6-0.9 \mathrm{mg}$ DON/kg in feed (Friend et al. 1982; Young et al. 1983; Bergsjø et al. 1993; Øvernes et al. 1997). The tolerance to NIV was not reviewed by EFSA (2004f) although it was acknowledged that feeds containing DON could also contain NIV and acetyl derivatives of DON and NIV.

The tolerance of pigs to both DON (Williams et al. 1988) and NIV (Williams and Blaney 1994) in naturally contaminated grain in Australia has been tested. Results were similar in type and magnitude to those reported elsewhere. Vomiting at high intakes (DON only) and persistent feed refusal (with both DON and NIV) were the only adverse effects noted with the tolerance $\sim 1 \mathrm{mg} / \mathrm{kg}$; feed conversion was only affected when levels exceeded 8-9 mg $\mathrm{DON} / \mathrm{kg}$ feed. It is considered that a guidance level of $0.5 \mathrm{mg} / \mathrm{kg}$ DM has a safety margin and is attainable in Australia pig diets without serious impact on grain and feed producers. It is noted that the slightly reduced feed intakes has more impact on young grower pigs than in older pigs which are often restrictively fed. The USA guideline is $1 \mathrm{mg} / \mathrm{kg} \mathrm{DM}$ in the total diet of pigs (USFDA 2010). 
Chickens have been reported to be more tolerant to DON than pigs with no effects on feed intake and growth until dietary concentrations reach $14 \mathrm{mg} / \mathrm{kg}$ although slight effects on liver and gizzard weights of chickens fed $9 \mathrm{mg} / \mathrm{kg}$ were reported (EFSA 2004f). However, Australian broilers have shown a little more susceptibility. Using naturally contaminated Australian wheat, chickens offered a choice between diets containing $12 \mathrm{mg} \mathrm{DON} / \mathrm{kg}$ and control diets strongly selected against the DON-containing diet and when given no choice, intakes were down and daily gain was reduced by $12 \%$ (Mannion and Blaney 1988). Daily gain also declined by 3-8\% in chickens fed maize-based diets containing 3-6 mg NIV/kg (Kopinski et al. 1991). A guidance level of $2 \mathrm{mg} / \mathrm{kg}$ DM, rather than the United States Food and Drug Administration guideline of $5 \mathrm{mg} / \mathrm{kg}$ DM in respect to either DON or NIV in the total diet of broilers allows a safety margin. Ducks and hens also appear to tolerate 3-5 mg DON/kg (EFSA 2004f) and a guidance level of $2 \mathrm{mg} / \mathrm{kg} \mathrm{DM}$ is suitable for these species.

Cattle are also considered fairly tolerant to DON. Studies in Canada have shown $1.5 \mathrm{mg} / \mathrm{kg}$ was tolerated but transient reductions in feed intake were noted with $6.4 \mathrm{mg} / \mathrm{kg}$ (Trenholm et al. 1984). In Australia, severe feed refusal, depression and scouring was observed in calves fed triticale subsequently found to contain $30 \mathrm{mg} \mathrm{DON} / \mathrm{kg}$ (B. J. Blaney, unpubl. data). A guidance level of $2 \mathrm{mg} / \mathrm{kg} \mathrm{DM}$ in respect to either DON or NIV in the total diet appears suitable compared with the USA guideline of $10 \mathrm{mg} / \mathrm{kg}$ DM, with $5 \mathrm{mg} / \mathrm{kg}$ DM for young animals (USFDA 2010). Sheep tolerated 4-5 mg/kg without significant effects (EFSA 2004f). The USA guideline of $2 \mathrm{mg} / \mathrm{kg} \mathrm{DM}$ is considered applicable to sheep and species not mentioned above. Guidance levels for the sum of DON, NIV and their acetyl derivatives in the total diet are listed in Table 7.

\section{Ergot alkaloids}

Ergot alkaloids are a diverse group of up to 40 compounds, comprising ergopeptides, clavines, lysergic acids and lysergic acid amides, produced by members of the fungal family Clavicipitaceae. Members of the family noteworthy on the basis of toxicity to animals include C. purpurea (infecting rye, rye grass, wheat, barley and oats), C. paspali (infecting Paspalum spp. of grasses), C. fusiformis (infecting millet) and C. africana (infecting sorghum). Other toxic members of the Clavicipitaceae include endophytic fungi of grasses, such as Neotyphodium coenophialum-infecting tall fescue and $N$. lolii-infecting perennial rye grass.

Ergot alkaloids are produced as the fungus develops, but are eventually concentrated in the hard-bodied resting stage of the fungus, the sclerotium. These sclerotia can fall to the ground and repeat the life cycle, or be harvested with the grain. Mature sclerotia vary in number and size from a few millimetres to more than $4 \mathrm{~cm}$ long according to the host plant (Kamphues and Drochner 1991; Meyer 1999) and differ in mass from a few grams to $25 \mathrm{~g}$ for 100 sclerotia. Ergot sclerotia also vary in colour from white (C. tripsaci), to brown (C. glabra) to yellow (C. hirtella) and purplish-brown (C. purpurea). Sclerotia also show significant differences in their total alkaloid content, which varies between 0.01 and $0.21 \%$ (Lorenz 1979; Wolff 1989) and in the alkaloid profile.
Rye ergot: (C. purpurea) can produce a range of alkaloids, including ergotamine, ergosine, ergocristine, ergocryptine, ergocornine and ergonovine (ergometrine) with the composition and content of sclerotia from different countries varying considerably (Young and Chen 1982). The alkaloid profiles of ergot sclerotia from south-western and eastern Australia are very similar. Ergotamine and ergocryptine are the major components with lesser concentrations of ergocornine and ergosine (Blaney et al. 2009). Ergot alkaloids may be converted to their $\mathrm{C} 8$ epimers on storage (i.e. epimerisation at position C8). A large proportion of the alkaloid content of sclerotia is represented by these epimers and it is unclear how much is present in developing sclerotia and how much is a result of isomerisation during storage. While relatively inactive in laboratory animal models (Stoll 1952; Goodman et al. 2011) there is insufficient information on the potential for the epimers to be converted back to active isomers in the rumen and risk assessment should consider the total alkaloid content of feed (Blaney et al. 2009).

Rye ergot infects annual rye grass (Lolium rigidum), particularly in south-eastern and south-western Australia (Reed et al. 2005). Infection of cereal crops, including rye, oats, wheat and barley is rare in Australia mainly due to the dry conditions prevailing during flowering of these crops but occurs in Europe and North America (Blaney et al. 2009). Consequently poisoning of livestock occurs only occasionally and in a few localities either as a result of grazing infected rye grass or if rye grass is not controlled in wheat or barley crops and grain becomes contaminated with ergot sclerotia during harvest (Blaney et al. 2009). Management of contamination of stock food might need to consider levels in grain and in hays prepared from infected pastures. Only the situation of ergot bodies in grain is considered here.

There is negligible transfer of rye ergot alkaloids from feed to edible tissues, milk or eggs (Whittemore et al. 1976, 1977; Parkheava 1979; Young and Marquardt 1982; Wolff et al. 1995; Mainka et al. 2005; Schumann et al. 2007, 2009). There is insufficient risk to human health in Australia from ergot alkaloids and their metabolites in food of animal origin to justify regulation of ergot sclerotia in animal feed on the basis of human health risks.

Ergot alkaloids affect animal production and setting of guidance levels for ergot and ergot alkaloids in stock foods is justified on this basis. Ruminants appear to be more sensitive to the effects of ergot than monogastric animals. The threshold tolerance of cattle and sheep for ergot alkaloids is not clear. In the few Australian cases of livestock poisoning severe hyperthermia was observed in ruminants fed 1-3 mg alkaloids/ $\mathrm{kg}$. To avoid severe poisoning it was suggested (Blaney et al. 2009) that the total alkaloid content of feed should be restricted to $<0.4 \mathrm{mg} / \mathrm{kg}$, which for sclerotia with an alkaloid content of $\sim 0.2 \%$ equated to the existing $0.02 \%$ limit for ergot sclerotes in stock food in Queensland (Qld 1997).

In a study in Australia, Bourke (2003) produced hyperthermia in cattle fed at the estimated equivalent of $1 \mathrm{mg}$ alkaloids $/ \mathrm{kg}$ in feed. However, he concluded that stock exposure to sunlight appears to be a critical factor in a particularly lethal form of hyperthermia in cattle and sheep and that toxins other than ergot alkaloids could be involved such as the ergochromes (Franck 1969; Buchta and Cvak 1999). Bourke (2003) suggested that feed 
likely to contain rye ergot should be avoided for ruminant feed, particularly in feedlot rations. For practical purposes it is preferred to propose a low level rather than a zero tolerance and a level of $0.01 \%$ ergot sclerotia in the total diet of cattle, goats and sheep is proposed, with an equivalent alkaloid content limit of $0.2 \mathrm{mg} / \mathrm{kg}$. This limit is lower than that suggested by Blaney et al. (2009), and lower than current state regulations, but given the very low frequency of contamination of bulk grain in Australia, it appears achievable by industry and consistent with the principle of as-low-as-reasonably-achievable.

Pigs and poultry are a better option for use of lightly contaminated grain than ruminants apart from the serious risk of agalactia in sows fed ergot before farrowing, due to the inhibitory effects of ergot alkaloids on release of prolactin (Anderson and Werdin 1977; Kopinski et al. 2007). In one Canadian study (Dignean et al. 1986) milk production was not affected when sows were fed $0.2 \%$ rye ergot $(4.5 \mathrm{mg}$ alkaloids/kg of diet) from breeding until weaning, but the authors noted that their results were apparently at variance with other studies showing agalactia produced by lower ergot concentrations. Studies with sorghum ergot fed to sows before farrowing, found adverse effects on milk production at alkaloid concentrations of 1.4-7 mg/kg (Kopinski et al. 2007), but higher concentrations were tolerated after lactation had commenced (Kopinski et al. 2008c). Nevertheless a concentration of $0.02 \%$ rye ergot $(0.4 \mathrm{mg}$ alkaloids $/ \mathrm{kg})$ should provide an adequate safety margin for weaner and breeder pigs. The tolerance of nonlactating pigs is also not clear but a Canadian study (Oresanya et al. 2003) suggested maximum tolerances of $0.1 \%$ ergot $(2 \mathrm{mg}$ alkaloid $/ \mathrm{kg}$ ) and $0.05 \%$ based on growth rates and feed intakes respectively for weaner pigs (7-20 kg liveweight). Other studies have shown that grower and finisher pigs are more resistant and $10-15 \mathrm{mg} / \mathrm{kg}$ can be tolerated with only minor effects on feed intakes that can be masked with palatable ingredients (Whittemore et al. 1977; Mainka et al. 2005; Kopinski et al. 2008a, 2008b, 2008c). One Australian study (Bakau et al. 1988) found reductions in growth rate and feed intake of pigs fed $0.75 \%$ ergot (alkaloid content not reported), which were exacerbated by higher temperatures $\left(35^{\circ} \mathrm{C}\right)$. On the basis of the above a level of $0.1 \%$ rye ergot ( $2 \mathrm{mg}$ alkaloids $/ \mathrm{kg}$ ) is proposed for grower and finisher pigs.

Various studies have shown that chickens are tolerant of rye ergot at a concentration of $0.5 \%$, but $1-5 \%$ progressively affects feed intake, feed conversion and growth rates (Rotter et al. 1985a, 1985b; Bakau and Bryden 1987). A guidance level for poultry of $0.2 \%$ rye ergot ( $4 \mathrm{mg}$ alkaloids $/ \mathrm{kg}$ ) provides an additional safety margin. Guidance levels for rye ergot or total rye ergot alkaloids in the total diet are listed in Table 7.

Sorghum ergot: $C$. africana is one of three species of ergot-infecting sorghum and related species, the others being C. sorghi and C. sorghicola, but only C. africana has so far been identified in Australia (Blaney et al. 2006). The main alkaloid produced by $C$. africana is dihydroergosine (DHES) (>80\%), with dihydroelymoclavine and festuclavine as minor components (Blaney et al.2003) and the three alkaloids occur in fairly constant relative proportions. As with other ergot fungi, sorghum ergot infects sorghum plants during flowering, and begins to replace the ovaries of infected flowers with a fungal body, the sphacelium. About 1 week after flowering, the sphacelium forces the floret open and infection is signalled by copious release of sticky honeydew (Frederickson et al. 1993). Gradually, in parallel with grain development which occurs over the next 4 weeks, this sphacelial tissue is replaced by harder sclerotial tissue (Frederickson and Odvody 1999). Only occasionally, in circumstances not clearly understood, a fully mature sclerotium may be formed (the hard walled, resting stage of the fungus). Low concentrations of DHES are produced by the sphacelial tissue and are present in honeydew (1-10 mg/kg, Blaney et al. 2006), but by far the most is produced by the sclerotial tissue (Mantle 1973; Blaney et al. 2006). Following its initial discovery in Australia in 1996 (Ryley et al. 1996), sorghum ergot was found to be present in all significant sorghumgrowing areas of Australia with infection mainly associated with late-planted crops flowering in cold weather when pollination is impaired. Sorghum ergot contamination of grain differs from that of rye ergot in that fully mature sclerotia are rarely formed, and 'ergot' in sorghum is defined as the total weight of all ergot bodies, including mature sclerotia, sphacelia with glumes attached, and sphacelia overgrown with sporodochia of the ergot saprophyte Cerebella spp. The average concentration of alkaloids in 'sorghum ergot' are therefore much less $(0.02 \%$ compared with $0.2 \%$ in mature sclerotia), but the relationship between 'ergot' and alkaloid concentration is poor (Kopinski et al. 2008b). In consequence, $\%$ ergot only provides a guide to contamination, which should be supported with alkaloid assay.

No residue data are available in milk or meat, but studies with related compounds (rye ergot alkaloids) show rapid metabolism in the rumen to base compounds (lysergic acid, etc), which retain pharmacological activity. One study has shown that no residues of DHES $(<5 \mu \mathrm{g} / \mathrm{kg})$ occur in eggs from hens fed high concentrations of sorghum ergot (Dingle et al. 2003). Consequently, there appears no reason to restrict sorghum ergot alkaloids in livestock feed in order to protect human health, unless concern should be raised in the future over the fate of alkaloid metabolites. Restrictions are therefore only warranted to protect livestock health.

Sorghum ergot alkaloids have similar effects as rye ergot alkaloids in reducing circulating prolactin concentrations, with severe impact on milk production of sows (Kopinski et al. 2007, 2008c) and cows (Moss et al. 1999; Blaney et al. 2000c). They also have vasopressor effects, reducing peripheral blood circulation and interfering with heat regulation in cattle (Blaney et al. 2001).

The growth and fattening of steers managed under feedlot conditions were severely affected at sorghum-ergot alkaloid concentrations of $1.1 \mathrm{mg} / \mathrm{kg}$ and over (Blaney et al. 2011). In experiments conducted by McLennan et al. (2001) in summer-autumn and in winter-spring, Hereford steers were fed a grain-based concentrate ration with alkaloid concentrations in the grain component of 1.5-12 mg DHES/kg. Ergot increased susceptibility of the steers to heat stress (shown by excessive salivation, panting, and excessive drinking/urination). Even very low concentrations of ergot alkaloids impair performance of cattle in feedlots, and the effects are more severe during hot, humid weather. It is proposed that sorghum ergot alkaloids in the total diet of non-lactating ruminants should be restricted to $0.3 \mathrm{mg}$ alkaloids $/ \mathrm{kg}$. This will most commonly be equivalent to $0.1 \%$ ergot, but could rarely but conceivably be present in a sample 
containing $0.02 \%$ of mature sclerotia (Kopinski et al. 2008c). Consequently, the proposed guidance limit for ergot should be supported by physical observation of the presence or absence of mature sclerotia, and by alkaloid assay when risks are higher.

Dairy cows are also very susceptible to sorghum ergot, with hyperthermia, reduced feed intakes and pronounced decline in milk production (Moss et al. 1999; Blaney et al. 2000a). In cows exposed to sorghum ergot, intakes of 2 and $4 \mathrm{mg} /$ head.day produced little effect on grain consumption and milk production while at 8 and $16 \mathrm{mg} /$ head.day milk yields declined from the start of feeding. Sorghum intakes were $5 \mathrm{~kg} /$ head.day, putting the tolerated level at $0.8 \mathrm{mg} / \mathrm{kg}$. Assuming the total feed intake including pasture to be $\sim 15 \mathrm{~kg} \mathrm{DM} /$ day, the tolerated level in the total diet would be $0.3 \mathrm{mg}$ alkaloids $/ \mathrm{kg}$. High temperatures in subtropical Australia are already a major constraint on dairy cow production, and ergot alkaloids can exacerbate this. To allow a safety margin to account for the effects of temperature, a guidance maximum level of $0.03 \%$ ergot $(0.1 \mathrm{mg}$ alkaloids $/ \mathrm{kg})$ is proposed.

When fed to pre-farrowing sows, $1.5 \%$ ergot ( $7 \mathrm{mg}$ alkaloids/ $\mathrm{kg}$ ) caused complete agalactia, while minor reductions in milk production were observed at concentrations down to $0.3 \%$ ergot (1.4 mg alkaloids/kg) (Kopinski et al. 2007). After lactation was in full flow sows were less susceptible, but 3\% ergot (16 mg alkaloids/kg) still reduced milk production (Kopinski et al. $2008 \mathrm{c}$ ). When diets containing $0.3 \%$ sorghum ergot $(1.3 \mathrm{mg}$ alkaloid $/ \mathrm{kg}$ ) were fed to sows from 16 weeks before farrowing until weaning of piglets 4 weeks post-farrowing, no adverse effects were observed, although a trend for reduced plasma prolactin in first litter gilts suggested that this was near the level of tolerance (Kopinski et al. 2008c). The suggested guidance maximum level of $0.1 \%$ ergot or $0.3 \mathrm{mg}$ alkaloids $/ \mathrm{kg}$ provides a safety margin.

Grower and finisher pigs were shown tolerate up to $35 \mathrm{mg} / \mathrm{kg}$ alkaloids in short-term feeding (Blaney et al. 2000b) and $10 \mathrm{mg}$ alkaloids/kg (1-4\% ergot, depending on batch) over the entire grower-finisher period (Kopinski et al. 2008a, 2008b), providing that feeds are formulated to minimise nutritional deficiencies and some potential decrease in palatability. A guidance maximum level of $1 \%$ ergot ( $3 \mathrm{mg}$ alkaloids $/ \mathrm{kg}$ ) provides a safety margin. Young weaner pigs appear to be more susceptible to the effects of ergot alkaloid than older pigs, and lower limits for weaner diets are suggested.

Broiler chickens have been shown to be fairly resistant to the effects of sorghum ergot (Blaney et al. 2001). At alkaloid concentrations $\sim 15-20 \mathrm{mg} / \mathrm{kg}$ there are no significant effects on growth, feed conversion or mortality (Bailey et al. 1999). At $30 \mathrm{mg} / \mathrm{kg}$, there can be some depression in feed intake and growth, accompanied by slight increases in heart and liver weight. Layer hens also can tolerate sorghum ergot. Over a 6-week period where hens were fed $0,6,12$ or $24 \mathrm{mg}$ alkaloids/kg there were significant decreases in egg production and egg mass at the $24 \mathrm{mg} / \mathrm{kg}$ level, but not at lower concentrations. It was concluded that $6 \mathrm{mg}$ alkaloid $/ \mathrm{kg}$ would not significantly affect production (Dingle et al. 2003). A guidance maximum level is proposed for poultry at $6 \mathrm{mg}$ alkaloids/kg DM.

A standard exists in Queensland for ergot (Claviceps spp.) other than sorghum ergot (C. africana) of $200 \mathrm{mg} / \mathrm{kg}(0.02 \%)$ and for sorghum ergot (C. africana) of $3000 \mathrm{mg} / \mathrm{kg}(0.3 \%)$ (Qld 1997).

The currently legislated stock feed limit of $0.3 \%$ ergot by weight in sorghum grain equates to $\sim 1$ ergot body per 100 seeds or 30 ergot bodies per $100 \mathrm{~g}$ grain. The GTA standard is $0.1 \%$ sclerotia by weight for stock feed intended for feedlot cattle with a limit of $0.3 \%$ for all other uses (GTA 2011). Deliveries of sorghum with sclerotia concentrations higher than $0.3 \%$ will be rejected by grain merchants and those higher than $0.1 \%$ will be rejected by cattle feedlotters. Most commonly, a sorghum sample containing $0.3 \%$ ergot bodies will contain $\sim 1 \mathrm{mg}$ alkaloid $/ \mathrm{kg}$ (Kopinski et al. 2008b).

If ergot-contaminated grain is milled, between 80 and $90 \%$ of the ergot can be directed to the bran and shorts feed streams. These fractions are regularly destined for animal feed but there are no available data on contamination levels. Care needs to be taken that grain 'dockage' does not ultimately get routed into animal feed.

\section{Phomopsins}

Lupinosis is a mycotoxicosis caused by the ingestion of toxins, phomopsins, produced by the fungus Diaporthe toxica, which colonises lupin plants (Allen 1987; Williamson et al. 1994). Western Australia is the major lupin producer in the world, accounting for $70 \%$ of world production and lupin fodder and stubble has been used as a feed source in this region, primarily for sheep (Allen 2009). The main source of exposure of livestock has been through grazing on or feeding of fodder, with few documented reports of lupinosis from feeding seed, as commercial grading of seed to remove discoloured seeds (which are toxin containing) effectively manages this source (Petterson et al. 1997). The introduction of phomopsisresistant lupins has also greatly reduced the risk of lupinosis such that lupinosis is no longer considered a disease of major importance to livestock producers in Western Australia (Allen 2009). There are insufficient data available at this stage to propose guidance levels for phomopsins.

\section{Bacterial toxins}

Another group of bacterial toxins present in some pasture hay that is of importance to the livestock industry is corynetoxins.

\section{Corynetoxins}

Corynetoxins are a family of nucleosidyl glycolipid antibiotics that are produced by the bacterium Rathayibacter toxicus that can colonise the seed heads of grasses. A nematode vector (Anguina funestra) forms a nematode gall in the seed head of the grass and in this way carries the bacteria to the plant. Corynetoxins are produced as the plant senesces towards the end of the growing season. Ingestion of corynetoxin-contaminated feed then produces the neurological diseases annual ryegrass toxicity and flood plain staggers (Bryden et al. 1994; Edgar et al. 1994).

Corynetoxins are best managed on farm through the control of rye grass in pastures with herbicides, biological control measures such as the twist fungus (Dilophospora alopecuri), which can reduce the prevalence of the nematode vector and the use of resistant varieties of rye grass. Currently available data are not 
sufficient to allow a guidance maximum level to be proposed for corynetoxins.

\section{Interpretation of guidance maximum levels}

\section{Analytical methods and sampling}

In utilising maximum guidance levels care needs to be taken to ensure any analytical results relied upon to determine the suitability of feed are sufficiently accurate. Whitaker (2003) has reviewed issues of particular relevance to analysis of feed samples. Contamination of feed is often not uniform. This means that obtaining a representative sample of the load is critical in getting an accurate estimation of the extent of contamination. Additionally, a variety of test methods may be available for a particular contaminant, including enzyme-linked immunosorbent assay and liquid chromatography. Each test varies in accuracy, specificity and variability as well as speed of analysis, complexity and cost. Test results will vary when an analysis is conducted multiple times, and results will exhibit further variation when conducted by different analysts in different laboratories. Laboratory reports should indicate the uncertainty inherent in the final reported value. It is very important to ascertain if the method used by a particular laboratory will be sufficiently accurate. The uncertainty about results must be factored into risk management decisions. In Australia, the National Association of Testing Laboratories (NATA) accredits laboratories to perform specific tests in compliance with Australian Standard AS ISO/IEC 17025:2005. In order to be accredited by NATA, laboratories must validate their test methods to objectively demonstrate that the results produced by those methods are fit for purpose. Accredited laboratories must also estimate, and if requested, report the measurement uncertainty associated with their test results. It must be recognised that the uncertainty in results reported by laboratories only takes into account the potential variability in the laboratory analysis and does not include variation attributable to sampling.

\section{Application of guidance levels to field situations}

The use of recommended maximum guidance levels is illustrated below for lead. A feed or feed ingredient sampled for lead is considered acceptable if the concentration found is at a level below the relevant guidance maximum level. Where a guidance level has not been proposed for a feed ingredient the calculation is based on the total diet and includes feed as well as exposure from ingested soil. The examples below illustrate the use of relative bioavailability factors, however in most cases these are not available and would be assumed to be $100 \%$ (i.e. $r=1$ ).

In the following hypothetical example a feed premix for pigs has been analysed and found to contain $43 \mathrm{mg}$ lead/ $\mathrm{kg}$ DM. The inclusion rate of the premix in the complete feed is $5 \%$. There are no other sources of exposure as the pigs are not fed forage and have no access to soil. The form of lead in the premix is known to be lead oxide with the relative bioavailability assumed to be the highest listed in the Supplementary Material for lead oxide $(75 \%)$. The concentration of lead in the total diet is then $43 \times$ $0.05 \times 0.75=1.61 \mathrm{mg}$ lead $/ \mathrm{kg} \mathrm{DM}$. Concentrations of lead in tissues at slaughter should be less than relevant standards as the concentration calculated for lead in the total diet is below the guidance maximum level (of $5 \mathrm{mg} / \mathrm{kg}$ ).
Calculations for ruminants differ in that they usually have access to forage as well as soil. In the following calculation a premix containing $43 \mathrm{mg}$ lead/kg DM is incorporated in the complete feed for cattle at $5 \%$. It is assumed the cattle total diet comprises $50 \%$ complete feed, $45 \%$ forage containing $0.1 \mathrm{mg}$ lead $/ \mathrm{kg}$ DM and 5\% soil containing $1 \mathrm{mg}$ lead $/ \mathrm{kg}$ soil. The relative bioavailabilities are $75 \%$ for lead present as lead oxide in the premix, $100 \%$ for forage and $25 \%$ for soil. The concentration of lead in the total diet is then $0.5 \times(43 \times 0.05 \times 0.75)+0.45 \times(0.1 \times$ $1)+0.05 \times(1 \times 0.25)=0.86 \mathrm{mg}$ lead $/ \mathrm{kg} \mathrm{DM}$, below the guidance maximum level, suggesting the presence of lead in the premix does not represent a concern.

If feeds that exceed the maximum guidance levels listed here are fed to livestock, the livestock may need to be managed to ensure concentrations of contaminants are below relevant standards at slaughter, for example by ensuring a period where livestock are not exposed to the contaminant to allow tissue concentrations to decline to acceptable levels before slaughter.

\section{Conclusion}

A modern food production chain requires all participants to be confident in suppliers of inputs. In this regard transfer of information between participants is important to enable responsible decisions to be made in order to effectively manage risks.

The FeedSafe program (http://www.sfmca.com.au/feedsafe/ about_feedsafe/, accessed 15 October 2012) followed by most commercial feed mills in Australia has a quality assurance program that is audited by third party auditors on an annual basis. FeedSafe requires a documented raw material sourcing and purchasing program to be implemented to minimise potential product quality and safety risks.

The suggested guidance maximum levels for various contaminants in livestock feed should serve as a useful resource for those involved in feed production and assist in the development of meaningful Hazard Analysis Critical Control Points programs for control of feed contaminants.

There are several options for the management of contaminants in the production of food of animal origin. For example, purchase specifications can be developed for feed and feed ingredients, vendor declarations can be obtained from feed suppliers, restrictions can be put in place to manage the level of inclusion of a feed item in the total ration or diet, or feeding can be restricted to certain classes of animals based on the concentration of the contaminant present. Finally, animals can be placed on 'clean feed' for a period before slaughter.

\section{References}

Alcoser VHL, Velthuis AGJ, Hoogenboom LAP, van der Fels-Klerx HJ (2011) Financial impact of a dioxin incident in the Dutch dairy chain. Journal of Food Protection 74, 967-979. doi:10.4315/0362-028X.JFP10-350

Allen J (2009) Lupinosis in Western Australia. Australian Veterinary History Record 55, 13-17.

Allen JG (1987) Lupinosis. Veterinary Clinical Toxicology 103, 113-130.

Allen NK, Mirocha CJ, Aakhus-Allen S, Bitgood JJ, Weaver G, Bates F (1981a) Effect of dietary zearalenone on reproduction of chickens. Poultry Science 60, 1165-1174. doi:10.3382/ps.0601165 
Allen NK, Mirocha CJ, Weaver G, Aakhus-Allen S, Bates F (1981b) Effect of dietary zearalenone on finishing broiler chickens and young turkey poults. Poultry Science 60, 124-131. doi:10.3382/ps.0600124

Anderson JF, Werdin RE (1977) Ergotism manifested as agalactia and gangrene in sows. Journal of the American Veterinary Association 170, 1089-1091.

Baars AJ, van Beek H, Visser IJ, Vos G, van Delft W, Fennema G, Lieben GW, Lautenbag K, Nieuwenhuijs JH, de Lezenne Coulander PA (1992) Lead intoxication in cattle: a case report. Food Additives and Contaminants $\mathbf{9}$, 357-364. doi:10.1080/02652039209374082

Bailey CA, Fazzino JJ, Ziehr MS, Sattar M, Haq AU, Odvody G, Porter JK (1999) Evaluation of sorghum ergot toxicity in broilers. Poultry Science 78, 1391-1397.

Bakau BJK, Bryden WL (1987) Toxicity of ergots of Claviceps purpurea in chickens subject to heat stress. Proceedings of the Nutrition Society of Australia 12, 170.

Bakau BJK, Peacock AJ, Love RJ, Bryden WL (1988) Toxicity of ergots of Claviceps purpurea in growing pigs subjected to different ambient temperatures. Proceedings of the Nutrition Society of Australia 13, 136.

Barry TN, Blaney BJ (1987) Secondary compounds of forages. In 'The nutrition of herbivores'. (Eds JB Hacker, JH Ternouth) pp. 91-119. (Academic Press: Sydney)

Bergsjø B, Langseth W, Nafstad I, Jansen JH, Larsen HJ (1993) The effects of naturally deoxynivalenol-contaminated oats on the clinical condition, blood parameters, performance and carcass composition of growing pigs. Veterinary Research Communications 17, 283-294. doi:10.1007/ BF01839219

Biehl ML, Prelusky DB, Koritz GD, Hartin KE, Buck WB, Trenholm HL (1993) Biliary excretion and enterohepatic cycling of zearalenone in immature pigs. Toxicology and Applied Pharmacology 121, 152-159. doi:10.1006/taap.1993.1140

Blaney BJ (1985) Mycotoxins in crops grown in different climatic regions of Queensland. In 'Trichothecenes and other mycotoxins'. (Ed. J Lacey) pp. 97-108. (John Wiley and Sons, Ltd: Chichester)

Blaney BJ (1996) Fungal toxins and animals. In 'Fungi of Australia. Vol. 1B. Introduction - fungi in the environment'. (Eds K Mallett, C Grgurinovic) pp. 225-238. (Australian Biological Resources Study, CSIRO: Canberra)

Blaney BJ (2005) Plant and fungal toxins as contaminants of feed and meat. In 'Improving the safety of fresh meat'. (Ed. JN Sofos) pp. 77-101. (Woodhead Publishing, Ltd: Cambridge)

Blaney BJ, Dodman RL (1988) Production of the mycotoxins zearalenone, 4-deoxynivalenol and nivalenol, by isolates of Fusarium graminearum Groups 1 and 2 from cereals in Queensland. Australian Journal of Agricultural Research 39, 21-29. doi:10.1071/AR9880021

Blaney BJ, Dodman RL (2002) Production of zearalenone, deoxynivalenol, nivalenol, and acetylated derivatives by Australian isolates of Fusarium graminearum and F. pseudograminearum in relation to source and culturing conditions. Australian Journal of Agricultural Research 53, 1317-1326. doi:10.1071/AR02041

Blaney BJ, Gartner RJW, McKenzie RA (1981) The effects of oxalate in some tropical grasses on the availability to horses of calcium, phosphorus and magnesium. Journal of Agricultural Science, Cambridge 97, 507-514. doi: $10.1017 / \mathrm{S} 0021859600036820$

Blaney BJ, Gartner RJW, Head TA (1982) The effects of oxalate in tropical grasses on calcium, phosphorus and magnesium availability to cattle. Journal of Agricultural Science, Cambridge 99, 533-539. doi:10.1017/ S0021859600031208

Blaney BJ, Bloomfield RC, Moore CJ (1984a) Zearalenone intoxication of pigs. Australian Veterinary Journal 61, 24-27. doi:10.1111/j.17510813.1984.tb07126.x

Blaney BJ, Moore CJ, Tyler AL (1984b) Mycotoxins and fungal damage in maize harvested during 1982 in Far North Queensland. Australian Journal of Agricultural Research 35, 463-471. doi:10.1071/AR9840463
Blaney BJ, Ramsey MD, Tyler AL (1986) Mycotoxins and toxigenic fungi in insect-damaged maize harvested during 1983 in Far North Queensland. Australian Journal of Agricultural Research 37, 235-244. doi:10.1071/ AR9860235

Blaney BJ, Moore CJ, Tyler AL (1987) The mycotoxins 4-deoxynivalenol, zearalenone and aflatoxin in weather-damaged wheat harvested 19831985 in south-east Queensland. Australian Journal of Agricultural Research 38, 993-1000. doi:10.1071/AR9870993

Blaney BJ, Josey BJ, McKenzie RA, Ryley MJ, Downing JA (2000a) An assessment of the effect on beef cattle of grazing sorghum (Sorghum bicolor) infected with ergot (Claviceps africana). Australian Veterinary Journal 78, 124-125. doi:10.1111/j.1751-0813.2000. tb10542.x

Blaney BJ, Kopinski JS, Magee MH, McKenzie RA, Blight GW, Maryam R, Downing JA (2000b) Blood prolactin depression in growing pigs fed sorghum ergot (Claviceps africana). Australian Journal of Agricultural Research 51, 785-791. doi:10.1071/AR99132

Blaney BJ, McKenzie RA, Walters JR, Taylor LF, Bewg WS, Ryley MJ, Maryam R (2000c) Sorghum ergot (Claviceps africana) associated with agalactia and feed refusal in pigs and dairy cattle. Australian Veterinary Journal 78, 102-107. doi:10.1111/j.1751-0813.2000. tb10535.x

Blaney BJ, Kopinski JS, Murray S-A, McLennan SR, Moss RJ, Downing JA, Dingle JG (2001) Research on the toxicity of sorghum ergot and its alkaloids. In 'Proceedings of the fourth Australian sorghum conference. Kooralbyn, Queensland, 5-8 February 2001'. (Eds AK Borrell, RG Henzell) (CD-ROM) (Range Media Pty Ltd: Toowoomba, Qld)

Blaney BJ, Maryam R, Murray S-A, Ryley MJ (2003) Alkaloids of sorghum ergot pathogen (Claviceps africana): assay methods and variation between sclerotia/sphacelia. Australian Journal of Agricultural Research 54, 167-175. doi:10.1071/AR02095

Blaney BJ, Chakraborty S, Murray S-A (2006) Alkaloid production by isolates of the sorghum ergot pathogen (Claviceps africana) from Australia and other countries. Australian Journal of Agricultural Research 57, 1023-1028. doi:10.1071/AR05334

Blaney BJ, Fletcher MT, McKenzie RA, Reichmann KG (2008a) Natural toxin exposure of ruminants in northern Australia: managing the risks to food safety, trade and production. Project Report AHW.017. Meat \& Livestock Australia Limited, Sydney.

Blaney BJ, O'Keeffe K, Bricknell LK (2008b) Managing mycotoxins in maize: case studies. Australian Journal of Experimental Agriculture 48, 351-357. doi:10.1071/EA06095

Blaney BJ, Molloy JB, Brock IJ (2009) Alkaloids in Australian rye ergot (Claviceps purpurea) sclerotia: implications for food and stockfeed regulations. Animal Production Science 49, 975-982. doi:10.1071/ AN09030

Blaney BJ, McLennan SR, Kidd JF, Connell JA, McKenzie RA, Downing JA (2011) Effect of sorghum ergot (Claviceps africana) on the performance of steers (Bos taurus) in a feedlot. Animal Production Science 51, 156-166. doi:10.1071/AN10086

Bourke CA (2003) Evidence that enforced sunlight exposure can cause hyperthermia in cattle ingesting low levels of ergot of rye (Claviceps purpurea), when air temperatures and humidity conditions are only moderate. Australian Veterinary Journal 81, 553-558. doi:10.1111/ j.1751-0813.2003.tb12886.x

Brazil (2011) Resolução - RDC no. 7, de 18 de fevereiro de 2011 Republicação. Available at http://www.brasilsus.com.br/legislacoes/ rdc/107502-7.html [Verified 20 December 2011]

Bricknell LK, Blaney BJ, Ng JC (2008) Risk management for mycotoxin contamination of Australian maize. Australian Journal of Experimental Agriculture 48, 342-350. doi:10.1071/EA06096

Bruning-Fann CS, Kaneene JB (1993) The effects of nitrate, nitrite, and N-nitroso compounds on animal health. Veterinary and Human Toxicology 35, 237-253. 
Bryden WL (2009) Mycotoxins and mycotoxicoses: significance, occurrence and mitigation in the food chain. In 'General and applied toxicology'. 3rd edn. (Eds B Ballantyne, T Marrs, T Syversen) pp. 3259-3553. (John Wiley \& Sons Ltd: Chichester, UK)

Bryden WL (2012a) Food and feed, mycotoxins and the perpetual pentagram in a changing animal production environment. Animal Production Science 52, 383-397.

Bryden WL (2012b) Mycotoxin contamination of the feed supply chain: implications for animal productivity and feed security. Animal Feed Science and Technology 173, 134-158. doi:10.1016/j.anifeedsci.2011. 12.014

Bryden WL, Lloyd AB, Cumming RB (1980) Aflatoxin contamination of Australian animal feeds and suspected cases of mycotoxicosis. Australian Veterinary Journal 56, 176-180. doi:10.1111/j.1751-0813.1980. tb05674.x

Bryden WL, Trengove CL, Davis EO, Giesecke PR, Curran GC (1994) Corynetoxicosis of livestock: a nematode-bacterium disease complex associated with different grasses. In 'Plant-associated toxins: agricultural, phytochemical and ecological aspects'. (Eds SM Colegate, PR Dorling) pp. 410-415. (CAB International: Wallingford, UK)

Buchta M, Cvak L (1999) Ergot alkaloids and other metabolites of the genus Claviceps. Ergot: the genus Claviceps 6, 173-200.

Burgess L, Dodman R, Pont W, Mayers P (1981) Fusarium diseases of wheat, maize and grain sorghum in eastern Australia. In 'Fusarium: diseases, biology and taxonomy'. (Eds P Nelson, T Toussoun, R Cook) pp. 64-76. (Pennsylvania State University Press: University Park, PA)

Burren BG, Reichmann KG, McKenzie RA (2010) Reduced risk of acute poisoning in Australian cattle from used motor oils after introduction of lead-free petrol. Australian Veterinary Journal 88, 240-241. doi:10.1111/ j.1751-0813.2010.00577.x

Burritt EA, Provenza FD (2000) Role of toxins in intake of varied diets by sheep. Journal of Chemical Ecology 26, 1991-2005. doi:10.1023/ A: 1005565228064

Buzby JC, Chandran R (2003) The Belgian dioxin crisis and its effects on agricultural production and exports. In 'International trade and food safety: economic theory and case studies'. (Ed. Jean C. Buzby) November 2003, Agricultural Economic Report No. 828, United States Department of Agriculture. Available at http://www.ers.usda.gov/ publications/aer828/aer828.pdf [Verified 22 November 2012]

Byrne D, Gill P (2011) Lead poisoning in livestock. PrimeFact 413, 2nd edn. NSW Department of Primary Industries. Available at http://www. dpi.nsw.gov.au/_data/assets/pdf_file/0014/102416/Lead-poisoning-inlivestock.pdf [Verified 22 November 2012]

CAST (2003) 'Mycotoxins: risks in plant, animal, and human systems.' (Council for Agricultural Science and Technology: Ames. IA)

Cheeke PR (1998) 'Natural toxicants in feeds, forages and poisonous plants'. (Interstate Publishers, Inc.: Danville, IL)

Chi MS, Mirocha CJ, Kurtz HJ, Weaver GA, Bates F, Robison T, Shimoda W (1980a) Effect of dietary zearalenone on growing broiler chicks. Poultry Science 59, 531-536. doi:10.3382/ps.0590531

Chi MS, Mirocha GJ, Weaver GA, Kurtz HJ (1980b) Effect of zearalenone on female white leghorn chickens. Applied and Environmental Microbiology 39, 1026-1030.

Chile (2011) Reglamento Sanitario de los Alimentos, art. 169, decreto 977/96, del Ministerio de Salud. Available at http://www.sernac.cl/sernac2011/ descargas/leyes/decreto/ds_977-96_reglamento_alimentos.pdf [Verified 20 December 2011]

China (2005a) Maximum Residue Limits for Pesticides in Food. Standard GB2763-2005.

China (2005b) Maximum Levels of Contaminants in Food. Standard GB2762-2005.

China (2011) Maximum Levels of Mycotoxins in Food. Standard GB27612011.
Codex (2010) Codex general standard for contaminants and toxins in food and feed. CODEX STAN 193-1995, adopted 1995; revised 1997, 2006, 2008, 2009; amended 2009, 2010. Available at http://www.codexalimentarius. org/standards/list-of-standards/en/ [Verified 20 December 2011]

Codex (2011) Pesticide residues in food and feed, Codex Pesticides Residues in Food Online Database. Available at http://www.codexalimentarius.net/ pestres/data/index.html [Verified 20 December 2011]

Covaci A, Voorspoels S, Schepens P, Jorens P, Blust R, Neels N (2008) The Belgian PCB/dioxin crisis -8 years later: an overview. Environmental Toxicology and Pharmacology 25, 164-170. doi:10.1016/j.etap.2007. 10.003

D'Mello JPF (2004) Contaminants and toxins in animal feed. In 'Assessing quality and safety of animal feeds, FAO Animal Production and Health 160'. pp. 107-128. (Food and Agriculture Organisation: Rome)

DAFF (2004), Dioxins in Agricultural Commodities in Australia, National Dioxins Program Technical Report No. 8, Australian Government Department of the Environment and Heritage, Canberra. Available at http://www.environment.gov.au/settlements/publications/chemicals/ dioxins/report-8/pubs/report-8.pdf [Verified 19 December 2011]

Dairy Australia (2011) A review of facial eczema (Pithomycotoxicosis). Report of the Dairy Australia Facial Eczema Working Group, November 2011. Available at http://www.dairyaustralia.com.au/ /media/ Documents/Animals-feed-and-environment/Feeding\%20cows/Facial $\%$ 20eczema/DA\%20Facial\%20Eczema\%20review\%20booklet.ashx [Verified 19 December 2011]

di Menna ME, Lauren DR, Holland PT (1985) Presence of zearalenone in New Zealand pasture leaves. New Zealand Veterinary Journal 33, 193. doi:10.1080/00480169.1985.35232

Dignean MA, Schiefer HB, Blair R (1986) Effects of feeding ergotcontaminated grain to pregnant and nursing sows. Journal of Veterinary Medicine A 33, 757-766. doi:10.1111/j.1439-0442.1986. tb00588.x

Dingle JG, Blaney BJ, Molloy JB, Fletcher TI, Murray S-A, Serrao E (2003) Use of ergot affected sorghum in layer diets: quality assurance of eggs. In 'Australian Poultry Science Symposium. 15th Australian Poultry Symposium'. (Ed. RAE Pym) p. 161-163. (University of Sydney: Sydney)

EC (1978) Report of the Scientific Committee for Animal Nutrition on the Effects of Nitrates in Feedingstuffs. Opinion expressed 19 April 1978. Available at http://ec.europa.eu/food/fs/sc/oldcomm6/other/17_en.pdf [Verified 25 January 2012]

EC (2003) Commission Directive 2003/100/EC of 31 October 2003 amending Annex I to Directive 2002/32/EC of the European Parliament and of the Council on undesirable substances in animal feed. Official Journal of the European Union L 285, 33-37.

EC (2006a) Commission Directive 2006/13/EC of 3 February 2006 amending Annexes I and II to Directive 2002/32/EC of the European Parliament and of the Council on undesirable substances in animal feed as regards dioxins and dioxin-like PCBs. Official Journal of the European Union L 32, $44-53$

EC (2006b) Commission Regulation (EC) No 1881/2006 of 19 December 2006 setting maximum levels for certain contaminants in foodstuffs. Official Journal of the European Union L 364, 5-24

Edgar JA, Cockrum PA, Stewart PL, Anderton NA, Payne AL (1994) Identification of corynetoxins as the cause of poisoning associated with Annual Beard Grass (Polypogon monspeliensis (L) Desf.) and Blown Grass (Agrostis avenacea C. Gemelin). In 'Plant-associated toxins: agricultural, phytochemical and ecological aspects'. (Eds SM Colegate, PR Dorling) pp. 393-398. (CAB International: Wallingford, UK)

EFSA (2004a) Opinion of the Scientific Panel on Contaminants in the Food Chain on a request from the Commission related to cadmium as undesirable substance in animal feed. Adopted on 2 June 2004. The EFSA Journal 72, 1-24. 
EFSA (2004b) Opinion of the Scientific Panel on Contaminants in the Food Chain on a request from the Commission related to lead as undesirable substance in animal feed. Adopted on 2 June 2004. The EFSA Journal 71, $1-20$.

EFSA (2004c) Opinion of the Scientific Panel on Contaminants in the Food Chain on a request from the Commission related to aflatoxin B1 as undesirable substance in animal feed. The EFSA Journal 39, 1-27.

EFSA (2004d) Opinion of the Scientific Panel on Contaminants in the Food Chain on a request from the Commission related to ochratoxin A (OTA) as undesirable substance in animal feed. The EFSA Journal 101, $1-36$.

EFSA (2004e) Opinion of the Scientific Panel on Contaminants in the Food Chain on a request from the Commission related to zearalenone as undesirable substance in animal feed. The EFSA Journal 89, 1-35.

EFSA (2004f) Opinion of the Scientific Panel on Contaminants in the Food Chain on a request from the Commission related to deoxynivalenol (DON) as undesirable substance in animal feed. The EFSA Journal 73, 1-41.

EFSA (2005a) Opinion of the Scientific Panel on Contaminants in the Food Chain on a request from the Commission related to fumonisins as undesirable substances in animal feed. The EFSA Journal 235, 1-32.

EFSA (2008) Scientific Opinion of the Panel on Contaminants in the Food Chain on a request from the European Commission on gossypol as undesirable substance in animal feed. The EFSA Journal 908, 1-56.

EFSA (2009) Nitrite as undesirable substances in animal feed. Scientific opinion of the panel on contaminants in the food chain. Adopted on 25th March 2009. The EFSA Journal 1017, 1-47.

EFSA (2010a) EFSA Panel on Contaminants in the Food Chain (CONTAM); scientific opinion on polybrominated biphenyls (PBBs) in food. EFSA Journal 8, 1789. doi:10.2903/j.efsa.2010.1789

EFSA (2010b) EFSA Panel on Contaminants in the Food Chain (CONTAM) and EFSA Panel on Food Contact Materials, Enzymes, Flavourings and Processing Aids (CEF); scientific opinion on melamine in food and feed. EFSA Journal 8, 1573. doi:10.2903/j.efsa.2010.1573

EFSA (2011) EFSA Panel on Additives and Products or Substances used in Animal Feed (FEEDAP); scientific opinion on the safety of hemp (Cannabis genus) for use as animal feed. EFSA Journal 9, 2011. [41 pp.]

Eriksen GS, Pettersson H(2004) Toxicological evaluation of trichothecenes in animal feed. Animal Feed Science and Technology 114, 205-239. doi:10.1016/j.anifeedsci.2003.08.008

EU (2011a) EU Pesticides database, Pesticide EU-MRLs Regulation (EC) No 396/2005. Available at http://ec.europa.eu/sanco_pesticides/public/ index.cfm [Verified 20 December 2011]

EU (2011b) Commission Regulation(EU) No 1259/2011 of 2 December 2011 amending Regulation (EC) No. 1881/2006 as regards maximum levels for dioxins, dioxin-like PCBs and non dioxin-like PCBs in foodstuffs. Official Journal of the European Union L 320, 18-23

FAO (2004) Worldwide regulations for mycotoxins in food and feed in 2003. FAO Food and Nutrition Paper 81, Food and Agriculture Organization of the United Nations, Rome 2004. Available at http://www.fao.org/docrep/ 007/y5499e/y5499e00.htm\#Contents [Verified 19 December 2011]

Fletcher MT, McKenzie RA, Reichmann KG, Blaney BJ (2011a) Risks from plants containing pyrrolizidine alkaloids for livestock and meat quality in northern Australia. In 'Poisoning by plants, mycotoxins and related toxins'. (Eds F Riet-Correa, J Pfister, AL Schild, T Wierenga) pp. 208-214. (CAB International: Wallingford, UK)

Fletcher MT, Brock IJ, Reichmann KG, McKenzie RA, Blaney BJ (2011b) Norsequiterpene glycosides in bracken ferns (Pteridium esculentum and Pteridium aquilinum subsp. wightianum) from eastern Australia. Journal of Agricultural and Food Chemistry 59, 5133-5138. doi:10.1021/jf104267c

Forsyth DM, Yoshizawa T, Morooka N, Tuite J (1977) Emetic and refusal activity of deoxynivalenol to swine. Applied and Environmental Microbiology 34, 547-552.
Foster BC, Trenholm HL, Friend DW, Thompson BK, Hartin KE (1986) Evaluation of different sources of deoxynivalenol (vomitoxin) fed to swine. Canadian Journal of Animal Science 66, 1149-1154. doi:10.4141/ cjas86-128

Francis RG, Burgess LW (1977) Characteristics of two populations of Fusarium roseum 'Graminearum' in eastern Australia. Transactions of the British Mycological Society 68, 421-427. doi:10.1016/S0007-1536 (77)80196-4

Franck B (1969) Structure and biosynthesis of the ergot pigments. Angewandte Chemie International Edition 8, 251-260. doi:10.1002/ anie. 196902511

Frederickson DE, Odvody GN (1999) Sorghum ergot distinguishing sphacelia and sclerotia of Claviceps africana in seed. Texas AgLife Extension Service L-5315 6-99. Available at http://repository.tamu.edu/handle/ 1969.1/86830 [Verified 20 December 2011]

Frederickson DE, Mantle PG, De Milliano WAJ (1993) Windborne spread of ergot disease (Claviceps africana) in sorghum A-lines in Zimbabwe. Plant Pathology 42, 368-377. doi:10.1111/j.1365-3059. 1993.tb01514.x

Friend DW, Trenholm HL, Elliot JI, Thompson BK, Hartin KE (1982) Effect of feeding vomitoxin-contaminated wheat to pigs. Canadian Journal of Animal Science 62, 1211-1222. doi:10.4141/cjas82-141

Fries GF (1995) A review of the significance of animal food products as potential pathways of human exposures to dioxins. Journal of Animal Science 73, 1639-1650.

FSANZ (2001) Generally Expected Levels (GELS) for metal contaminants. Additional guidelines to maximum levels in Standard 1.4.1 contaminants and natural toxicants. Available at http://www.food standards.gov.au/foodstandards/userguides/generallyexpectedlev1412. cfm [Verified 20 December 2011]

FSANZ (2003) 'The 20th Australian total diet survey: a total diet survey of pesticide residues and contaminants.' Food Standards Australia New Zealand: Canberra) ISBN 0642345910.

FSANZ (2004) Dioxins in food. Dietary exposure assessment and risk characterisation. Technical Report Series No. 27. Food Standards Australia New Zealand, March 2004. Available at http://www.food standards.gov.au/scienceandeducation/publications/dioxinsinfooddietary exposureassessmentandriskcharacterisation/ [Verified 20 December 2011]

FSANZ (2008) 'The 22nd Australian total diet study: a total diet study of five trace elements: iodine, selenium, chromium, molybdenum, and nickel.' Food Standards Australia New Zealand: Canberra) ISBN 978-0642-34561-5

FSANZ (2011) 'The 23rd Australian total diet study.' (Food Standards Australia New Zealand: Barton, ACT)

FSANZ (2012) Electronic version of the Australia New Zealand Food Standards Code. Available at http://www.foodstandards.gov.au/ foodstandards/foodstandardscode.cfm [Verified 31 May 2012]

Gardiner MR, Oldroyd B (1965) Avian aflatoxicosis. Australian Veterinary Journal 41, 272-276. doi:10.1111/j.1751-0813.1965.tb06559.x

Gilbert J, Şenyuva H (2005) Environmental contaminants and pesticides in animal feed and meat. In 'Improving the safety of fresh meat'. (Ed. JN Sofos) pp. 132-155. (Woodhead Publishing, Ltd: Cambridge)

Goodman LS, Brunton LL, Chabner B, Knollman B (2011) 'Goodman and Gilman's the pharmacological basis of therapeutics.' (McGraw-Hill Medical: New York)

Graham J (1982) Aflatoxin in peanuts: occurrence and control. Queensland Agricultural Journal 108, 119-122.

GTA (2011) 2010/11 GTA Commodity Standards. Grain Trade Australia. Available at http://www.graintrade.org.au/commodity_standards [Verified 20 December 2011]

Gumprecht LA, Smith GW, Constable PC, Haschek WM (2001) Species and organ specificity of fumonisin-induced endothelial alterations: potential role in porcine pulmonary edema. Toxicology 160, 71-79. doi:10.1016/ S0300-483X(00)00444-3 
Hart L (1965) Avian aflatoxicosis. Australian Veterinary Journal 41, 395-396. doi:10.1111/j.1751-0813.1965.tb04568.x

Harvey JM (1952) Chronic endemic fluorosis of merino sheep in Queensland. Queensland Journal of Agricultural Science 9, 47-141.

Heres L, Hoogenboom R, Herbes R, Traag W, Urlings B (2010) Tracing and analytical results of the dioxin contamination incident in 2008 originating from the Republic of Ireland. Food Additives \& Contaminants: Part A 27, 1733-1744.

Hill BD, Blaney BJ (1980) Urochloa panicoides (liverseed grass) as a cause of nitrate poisoning. Australian Veterinary Journal 56, 256. doi:10.1111/ j.1751-0813.1980.tb15995.x

Hocking AD, Varelis P, Pitt JI, Cameron S, Leong SL (2003) Occurrence of ochratoxin A in Australian wine. Australian Journal of Grape and Wine Research 9, 72-78. doi:10.1111/j.1755-0238.2003.tb00234.x

Hong Kong (2011) Harmful Substances in Food Regulations Regulation 3A. Prohibition of import and sale of fish, meat or milk containing prohibited substances. Hong Kong Centre for Food Safety. Available at http://www.cfs.gov.hk/english/food_leg/food_leg_hs.html\#hs_reg3 [Verified 20 December 2011]

Huff WE, Wyatt RD, Hamilton PB (1975) Nephrotoxicity of dietary ochratoxin A in broiler chickens. Applied Microbiology 30, 48-51.

IARC (1993) Some naturally occurring substances: food items and constituents, heterocyclic aromatic amines and mycotoxins, Monograph 56, Lyon: International Agency for Research on Cancer. Available at http:// monographs.iarc.fr/ENG/Monographs/vol56/volume56.pdf [Verified 20 December 2011]

Ichinoe M, Kurata H, Sugiura Y, Ueno Y (1983) Chemotaxonomy of Gibberella zeae with special reference to production of trichothecenes and zearalenone. Applied and Environmental Microbiology 46, 1364-1369.

Jacela JY, DeRouchey JM, Tokach MD, Goodband RD, Nelssen JL, Renter DG, Dritz SS (2010) Feed additives for swine: fact sheets - high dietary levels of copper and zinc for young pigs, and phytase. Journal of Swine Health and Production 18, 87-91.

James LF, Butcher JE (1972) Halogeton poisoning of sheep: effect of high level oxalate intake. Journal of Animal Science 35, 1233-1238.

James MP, Seawright AA, Steele DP (1971) Experimental acute ammonium oxalate poisoning of sheep. Australian Veterinary Journal 47, 9-17. doi:10.1111/j.1751-0813.1971.tb09195.x

Japan (2011a) Maximum Residue Limits (MRLs) List of Agricultural Chemicals in Foods, Positive List System for Agricultural Chemical Residues in Foods. The Japan Food Chemical Research Foundation. Available at http://www.m5.ws001.squarestart.ne.jp/foundation/search. html [Verified 20 December 2011]

Japan (2011b) Specifications and Standards for Foods, Food Additives, etc. Under the Food Sanitation Act (Abstract) 2010, April 2011. Japan External Trade Organisation. Available at http://www.jetro.go.jp/en/ reports/regulations/pdf/foodext201112e.pdf [Verified 20 December 2011]

Jard G, Liboz T, Mathieu F, Guyonvarc'h A, Lebrihi A (2011) Review of mycotoxin reduction in food and feed: from prevention in the field to detoxification by absorption or transformation. Food Additives and Contaminants Part A, 1-20, in press.

Kamphues J, Drochner W (1991) Mutterkorn in Futtermitteln-ein Beitrag zur Klärung moglicher mutterkornbedingter Schadensfälle. Tierarztliche Praxis 19, 1-7.

Ketterer PJ, Blaney BJ, Moore CJ, McInnes IS, Cook PW (1982) Field cases of aflatoxicosis in pigs. Australian Veterinary Journal 59, 113-118. doi:10.1111/j.1751-0813.1982.tb02743.x

Kim M, Choi S-W, Park JY, Kim D-G, Bong Y-H, Jang JH, Song SO, Chung GS, Guerrero P (2009) Dioxin contamination of Chilean pork from zinc oxide in feed. Organohalogen Compounds 71, 179-182.

Kolossova A, Stroka J, Breidbach A, Kroeger K, Ambrosio M, Bouten K, Ulberth F (2009) Evaluation of the effect of mycotoxin binders in animal feed on the analytical performance of standardised methods for the determination of mycotoxins in feed. JRC Scientific and Technical Reports EUR 23997 EN - 2009. European Commission Joint Research Centre, Institute for Reference Materials and Measurement. Available at http://irmm.jrc.ec.europa.eu/activities/mycotoxins/Documents/eur_ 23997_en.pdf [Verified 8 December 2011]

Kopinski JS, Blaney BJ, Barram KM, Young R (1991) Responses of broilers offered diets containing the mycotoxin nivalenol. In 'Recent advances in nutrition in Australia. University of New England, Armidale. 7-10 April'. (Ed. DJ Farrell) p. 30A. (University of New England: Armidale, NSW)

Kopinski JS, Blaney BJ, Downing JA, McVeigh JF, Murray S-A (2007) Feeding sorghum ergot (Claviceps africana) to sows before farrowing inhibits milk production. Australian Veterinary Journal 85, 169-176. doi:10.1111/j.1751-0813.2007.00139.x

Kopinski JS, Blaney BJ, Downing JA (2008a) Tolerance of pigs to sorghum ergot (Claviceps africana) during growth and finishing, and effect on conception of replacement gilts. Australian Journal of Experimental Agriculture 48, 672-679. doi:10.1071/EA07326

Kopinski J, Blaney BJ, Downing JA (2008b) Effect of 0.3\% sorghum ergot (Claviceps africana) in sow diets on plasma prolactin, lactation and piglet growth: regulatory implications. World Mycotoxin Journal 1, 475-482. doi:10.3920/WMJ2008.1047

Kopinski JS, Blaney BJ, Murray SA, Downing JA (2008c) Effect of feeding sorghum ergot (Claviceps africana) to sows during mid-lactation on plasma prolactin and litter performance. Journal of Animal Physiology and Animal Nutrition 92, 554-561. doi:10.1111/j.1439-0396.2007. 00747.x

Korea (2009) MRLs for pesticides 09 2009, Korean Food and Drug Administration. Available at http://eng.kfda.go.kr/file/PesiticideMRLs. pdf [Verified 20 December 2011]

Korea (2011) Food Code, Korean Food and Drug Administration. Available at http://eng.kfda.go.kr/index.php [Verified 20 December 2011]

Krogh P, Elling F, Hald B, Jylling B, Petersen VE, Skadhauge E, Svendsen CK (1976) Experimental avian nephropathy. Changes of renal function and structure induced by ochratoxin A-contaminated feed. Acta Pathologica et Microbiologica Scandinavica 84, 215-221.

Kuiper-Goodman T, Grant DL (2007) Ochratoxin A (First draft) WHO Food Additive Series 28. Available at http://www.inchem.org/documents/ jecfa/jecmono/v28je19.htm [Verified 20 December 2011]

Leslie JF, Marasas WFO (2001) Fusarium from sorghum: life in interesting times. In 'Proceeding of the 22nd biennial grain sorghum research and utilisation conference, 2001 sorghum industry conference. 18-20 February 2001. Nashville, Tennessee, USA'. pp. 76-83.

Lorenz K (1979) Ergot on cereal grains. CRC Critical Reviews in Food Science, and Nutrition 11, 311-354.

LPA (2011) Livestock Production Assurance. Available at http://www.mla. com.au/Meat-safety-and-traceability/On-farm-assurance/LPA [Verified 20 December 2011]

Lutze J, Derrick J, Korth W, MacLachlan DJ (2009) Monitoring of pesticides and veterinary drugs in Australian cattle: verification of the residue control system. Food Additives and Contaminants: Part B: Surveillance 2, 99-111. doi:10.1080/19440040903274003

MacLachlan DJ (2011) Estimating the transfer of contaminants in animal feedstuffs to livestock tissues, milk and eggs: a review. Animal Production Science 51, 1067-1078. doi:10.1071/AN11112

MacLachlan DJ, Bhula R (2008) Estimating the residue transfer of pesticides in animal feedstuffs to livestock tissues, milk and eggs: a review. Australian Journal of Experimental Agriculture 48, 589-598. doi:10.1071/EA07196

Madsen A, Mortensen HP, Hald B (1982a) Feeding experiments with ochratoxin A contaminated barley for bacon pigs. I. Influence on pig performance and residues. Acta Agriculturae Scandinavica 32, 225-239. doi:10.1080/00015128209435753 
Madsen A, Hald B, Lillehoj E, Mortensen HP (1982b) Feeding experiments with ochratoxin A contaminated barley for bacon pigs. 2. Naturally contaminated barely given for 6 weeks from $20 \mathrm{~kg}$ compared with normal barley supplemented with crystalline ochratoxin A and/or citrinin. Acta Agriculturae Scandinavica 32, 369-372. doi:10.1080/ 00015128209435333

Mainka S, Dänicke S, Böhme H, Ueberschär K-H, Polten S, Hüther L (2005) The influence of ergot-contaminated feed on growth and slaughtering performance, nutrient digestibility and carry-over of ergot alkaloids in growing-finishing pigs. Archives of Animal Nutrition 59, 377-395. doi:10.1080/17450390500352970

Mannion PF, Blaney BJ (1988) Responses of meat chickens offered 4-deoxynivalenol and zearalenone-containing wheat, naturally infected with Fusarium graminearum. Australian Journal of Agricultural Research 39, 533-540. doi:10.1071/AR9880533

Mantle PG (1973) Production of ergot alkaloids in vitro by Sphacelia sorghi. Journal of General Microbiology 75, 275-281. doi:10.1099/0022128775-2-275

Marasas WFO (1996) Fumonisins: history, worldwide occurrence and impact. In 'Fumonisins in food'. (Eds LS Jackson, JW DeVries, LB Bullerman) pp. 1-17. (Plenum Press: New York)

Maryamma KI, Manomohan CB, Nair MG, Ismail PK, Sreekumaran T, Rajan A (1992) Pathology of zearalenone toxicosis in chicken and evaluation of zearalenone residues in tissues. The Indian Journal of Animal Sciences 62, 105-107.

McKenzie RA, Blaney BJ, Connole MD, Fitzpatrick LA (1981) Acute aflatoxicosis in calves fed peanut hay. Australian Veterinary Journal 57, 284-286. doi:10.1111/j.1751-0813.1981.tb05816.x

McKenzie RA, Bell AM, Storie GJ, Keenan FJ, Cornack KM, Grant SG (1988) Acute oxalate poisoning of sheep by buffel grass (Cenchrus ciliaris). Australian Veterinary Journal 65, 26. doi:10.1111/j.17510813.1988.tb14926.x

McLennan SR, Blaney BJ, Kidd JF, Connell JA, Doogan V (2001) Effects of sorghum ergot on the performance of cattle in feedlots. [Abstract] In 'Proceedings from the fourth Australian sorghum conference. Kooralbyn, Queensland, 5-8 February 2001'. (Eds AK Borrell, RG Henzell) (CD-ROM) (Range Media Pty Ltd: Toowoomba, Qld)

Meyer A (1999) Mutterkorn in der Ration. Hannoversche Land- und Forstwirtsch. Zeitung 28, 32-33.

Miller JD (2008) Mycotoxins in small grains and maize: old problems, new challenges. Food Additives and Contaminants 25, 219-230. doi:10.1080/ 02652030701744520

Moore CJ, Blaney BJ, Spencer RA, Dodman RL (1985) Rejection by pigs of mouldy grain containing deoxynivalenol. Australian Veterinary Journal 62, 60-62. doi:10.1111/j.1751-0813.1985.tb14237.x

Moss RJ, Blaney BJ, Casey ND, Gobius NR, Jonsson NN (1999) Ergot (Claviceps africana) contamination of sorghum grain reduces milk production. Recent Advances in Animal Nutrition in Australia 12, 21A.

Müller HM, Lerch C, Müller K, Eggert W (1998) Kinetic profiles of ochratoxin $\mathrm{A}$ and ochratoxin alpha during in vitro incubation in buffered forestomach and abomasal contents from cows. Natural Toxins 6, 251-258. doi:10.1002/(SICI)1522-7189(199811/12)6:6<251:: AID-NT35>3.0.CO;2-P

Munkvold G, Desjardins A (1997) Fumonisins in maize: can we reduce their occurrence? Plant Disease 81, 556-565. doi:10.1094/PDIS.1997. 81.6 .556

NRC (2005) 'Mineral tolerance of animals.' 2nd rev. edn. (Committee on Minerals and Toxic Substances in Diets and Water for Animals, National Research Council. National Academies Press: New York)

NRS (1997) 'Metals in meat, National Residue Survey, 1997.' (NRS: Canberra)

NSW (2010) Stock Foods Regulation 2010. Available at http://www. legislation.nsw.gov.au/sessionalview/sessional/sr/2010-451.pdf [Verified 20 December 2011]
Olsen M, Mirocha CJ, Abbas HK, Johansson B (1986) Metabolism of high concentrations of dietary zearalenone by young male turkey poults. Poultry Science 65, 1905-1910. doi:10.3382/ps.0651905

Oresanya TF, Patience JF, Zijlstra RT, Beaulieu AD, Middleton DM, Blakey BR, Gillis DA (2003) Defining the tolerable level of ergot in the diet of weaned pigs. Canadian Journal of Animal Science 83, 493-500. doi:10.4141/A03-008

Øvernes G, Matre T, Sivertsen T, Larsen HJS, Langseth W, Reitan LJ, Jansen JH (1997) Effects of diets with graded levels of naturally deoxynivalenol-contaminated oats on immune response in growing pigs. Journal of Veterinary Medicine Series A. Animal Physiology, Pathology, and Clinical Veterinary Medicine 44, 539-550. doi:10.1111/ j.1439-0442.1997.tb01140.x

Page RK, Stewart G, Wyatt R, Bush P, Fletcher OJ, Brown J (1980) Influence of low levels of ochratoxin A on egg production, egg-shell stains, and serum uric-acid levels in Leghorn-type hens. Avian Diseases 24, 777-780. doi: $10.2307 / 1589815$

Park DL, Troxell TC (2002) US Perspective on mycotoxin regulatory issues. In 'Advances in Experimental Medicine and Biology, Vol. 504: Mycotoxins and food safety'. (Eds JW DeVries, MW Trucksess, LS Jackson) pp. 277-285. (Kluwer Academic/Plenum Publishers: New York)

Parkheava AI (1979) Excretion of ergot alkaloids with milk. Veterinariya (Moscow) 11, 76-77.

Petterson DS, Sipsas S, Mackintosh JB (1997) 'The chemical composition and nutritive value of Australian pulses.' 2nd edn. (Grains Research and Development Corporation: Canberra)

Pettersson H (2004) Controlling mycotoxins in animal feed. In 'Mycotoxins in food: detection and control'. Woodhead Publishing Series in Food Science, Technology and Nutrition No. 103. (Eds N Magan, M Olsen) pp. 262-304. (Woodhead Publishing: Cambridge, UK)

Pitt JI, Basilico JC, Abarca ML, Lopez C (2000) Mycotoxins and toxigenic fungi. Medical Mycology 38(Suppl. 1), 41-46.

Prior MG, Sisodia CS (1978) Ochratoxicosis in White Leghorn hens. Poultry Science 57, 619-623. doi:10.3382/ps.0570619

Puls R (1994) 'Mineral levels in animal health.' 2nd edn. (Sherpa International: Clearbrook)

Qld (1988) Stock Regulations 1988. Available at http://www.legislation.qld. gov.au [Verified 15 October 2012]

Qld (1997) Agricultural Standards Regulations 1997. Available at http:// www.legislation.qld.gov.au [Verified 15 October 2012]

Rachaputi N, Wright GC, Krosch S (2002) Management practices to minimise pre-harvest aflatoxin contamination in Australian peanuts. Australian Journal of Experimental Agriculture 42, 595-605. doi:10.1071/EA01139

Rahman MM, Abdullah RB, Wan Khadijah WE (2012) A review of oxalate poisoning in domestic animals: tolerance and performance aspects. Journal of Animal Physiology and Animal Nutrition, in press. doi:10.1111/j.1439-0396.2012.01309.x

Reed KFM, Moore DD (2009) A preliminary survey of zearalenone and other mycotoxins in Australian silage and pasture. Animal Production Science 49, 696-703. doi:10.1071/EA08164

Reed KFM, Page SW, Lean IJ (Eds) (2005) 'Perennial ryegrass toxicosis in Australia. Proceedings of a symposium held on Friday 18 March 2005 at Attwood, Victoria.' (Meat and Livestock Australia: Sydney)

Reichmann KG, Blaney BJ, Connor JK, Runge BM (1982) The significance of aflatoxin and ochratoxin in the diet of Australian chickens. Australian Veterinary Journal 58, 211-212. doi:10.1111/j.1751-0813.1982. tb00671.x

Robertson ID, Naprasnik A, Morrow D (1990) The sources of pesticide contamination in Queensland livestock. Australian Veterinary Journal 67, 152-153. doi:10.1111/j.1751-0813.1990.tb07740.x

Rotter RG, Marquardt RR, Young JC (1985a) Effect of ergot from different source and of fractionated ergot on the performance of growing chicks. Canadian Journal of Animal Science 65, 953-961. doi:10.4141/cjas85112 
Rotter RG, Marquardt RR, Crow GH (1985b) A comparison of the effect of increasing dietary concentration of wheat ergot on the performance of leghorn and broiler chicks. Canadian Journal of Animal Science 65, 963-974. doi:10.4141/cjas85-113

Rotter BA, Thompson BK, Lessard M, Trenholm HL, Tryphonas H (1994) Influence of low-level exposure to Fusarium mycotoxins on selected immunological and haematological parameters in young swine. Fundamental and Applied Toxicology 23, 117-124. doi:10.1006/faat. 1994.1087

Russia (2010) Food raw material and foodstuff - hygienic requirements for safety and nutrition value of foodstuff. SanPiN 2.3.2.1078-01, unofficial English translation. Available at http://ec.europa.eu/food/international/ trade/rf_allfoodprod_en.htm [Verified 20 December 2011]

Ryley MJ, Alcorn JL, Kochman JK, Kong GA, Thompson SM (1996) Ergot on Sorghum spp. in Australia. Australasian Plant Pathology 25, 214. doi:10.1071/AP96038

Safemeat (2007) Managing for cadmium minimisation in Australian livestock. Safemeat, Australia. Available at http://www.cadmiummanagement.org.au/documents/cadmium-livestock.pdf [Verified 15 November 2011]

Schumann B, Dänicke S, Meyer U, Ueberschär K-H, Breves G (2007) Effects of different levels of ergot in concentrates on the growing and slaughtering performance of bulls and on carry-over into edible tissue. Archives of Animal Nutrition 61, 357-370. doi:10.1080/17450390701556726

Schumann B, Lebzien P, Ueberschär K-H, Dänicke S (2009) Effects of the level of feed intake and ergot contaminated concentrate on ergot alkaloid metabolism and carry over into milk. Molecular Nutrition \& Food Research 53, 931-938. doi:10.1002/mnfr.200800319

Seawright AA, Groenendyk S, Silva KI (1970) An outbreak of oxalate poisoning in cattle grazing Setaria sphacelata. Australian Veterinary Journal 46, 293-296. doi:10.1111/j.1751-0813.1970.tb07900.x

Seifert KA, Aoki T, Baayen RP, Brayford D, Burgess L, Chulze S, Gamms W, Geiser D, de Gruyter J, Leslie JF, Logrieco A, Marasas WFO, Nirenberg HI, O'Donnell K, Rheeder J, Samuals GJ, Summerell BA, Thrane U, Waalwijk C (2003) The name Fusarium moniliforme should no longer be used. Mycological Research News 643-644. doi:10.1017/S095375 620323820X

Shanks G, Tabak P, Begg AP, Bryden WL (1995) An outbreak of acute leukoencephalomalacia associated with fumonisin intoxication in three horses. Australian Equine Veterinarian 13, 17-18.

Shaw FD, Eustace IJ (1993) Chemical residues in meat. In 'Meat '93. The Australian meat industry research conference. Gold Coast, Queensland, 11-13 October 1993'. Available at http://www.meatupdate.csiro.au/data/ Meat_93_28.pdf [Verified 20 December 2011]

Smith JF, Morris CA (2006) Review of zearalenone studies with sheep in New Zealand. Proceedings of the New Zealand Society of Animal Production 66, 306-310.

Smith JF, di Menna ME, McGowan LT (1990) Reproductive performance of Coopworth ewes following oral doses of zearalenone before and after mating. Journal of Reproduction and Fertility 89, 99-106. doi:10.1530/ jrf.0.0890099

Southwell R, Moore K, Manning W, Hayman P (2003) An outbreak of Fusarium head blight of durum wheat on the Liverpool Plains in northern New South Wales in 1999. Australasian Plant Pathology 32, 465-471. doi:10.1071/AP03061

Spencer A (2010) Factsheet: toxic weed seeds, Queensland Department of Primary Industries and Fisheries. Available at http://www.dpi.qld.gov.au/ 27_11766.htm [Verified 25 January 2012]

Stoll A (1952) Recent investigations on ergot alkaloids. In 'Progress in the chemistry of organic natural products'. (Ed. L Zechmeister) pp. 114-174. (Springer-Verlag: Vienna)

Suttle NF (2010) 'Mineral nutrition of livestock.' 4th edn. (CABI: Oxford)
Taiwan (2009a) 26 Standards for pesticide residue limits in livestock and poultry products 2009-12-24. Available at http://www.fda.gov.tw/eng/ people_laws_list.aspx?pages $=1 \&$ keyword=\&classifysn $=16$ [Verified 20 December 2011]

Taiwan (2009b) 23 Standard for the tolerance of polychlorinated biphenyl in foods. Food Sanitation Standards 2009-12-24. Available at http://www. fda.gov.tw/eng/people_laws_list.aspx?pages $=1 \&$ keyword $=\&$ classifysn $=16$ [Verified 20 December 2011]

Taiwan $(2009 c) 32$ Standard for the tolerance of heavy metals in edible offal of cattle, sheep, pig and poultry 2009-12-24. Available at http://www.fda. gov.tw/eng/people_laws_list.aspx?pages $=1 \&$ keyword $=\&$ classifysn $=16$ [Verified 20 December 2011]

Taiwan (2009d) 47 Standard for the tolerance of mycotoxins in foods 2009-12-04. Available at http://www.fda.gov.tw/eng/people_laws_list. aspx?pages $=1 \&$ keyword $=\&$ classifysn $=16$ [Verified 20 December 2011]

Tapia MO, Seawright AA (1984) Experimental ochratoxicosis A in pigs. Australian Veterinary Journal 61, 219-222. doi:10.1111/j.1751-0813. 1984.tb05993.x

Tinggi U (2003) Essentiality and toxicity of selenium and its status in Australia: a review. Toxicology Letters 137, 103-110. doi:10.1016/ S0378-4274(02)00384-3

Tobin NF (1988) Presence of deoxynivalenol in Australian wheat and triticale - New South Wales Northern Rivers region 1983. Australian Journal of Experimental Agriculture 28, 107-110. doi:10.1071/ EA9880107

Towers NR, Sprosen JM, Webber W (1995) Zearalenone metabolites in cycling and non-cycling cows. In 'Toxinology and food safety'. pp. 46-47. (Toxinology and Food Safety Research Group, Ruakura Research Centre: Hamilton, New Zealand)

Trenholm HL, Hamilton RMG, Friend DW, Thompson BK, Hartin KE (1984) Feeding trials with vomitoxin (deoxynivalenol)-contaminated wheat: effects on swine, poultry and dairy cattle. Journal of the American Veterinary Medical Association 185, 527-531.

Trenholm HL, Foster BC, Charmley LL, Thompson BK, Hartin KE, Coppock RW, Albassam MA (1994) Effects of feeding diets containing Fusarium (naturally) contaminated wheat or pure deoxynivalenol (DON) in growing pigs. Canadian Journal of Animal Science 74, 361-369. doi:10.4141/ cjas $94-049$

Ueno Y (1983) Historical background of trichothecene problems. In 'Trichothecenes - chemical, biological and toxicological aspects'. (Ed. Y Ueno) pp. 1-6. (Elsevier: Tokyo)

USFDA (2001a) Background paper in support of fumonisin levels in animal feed. Center for Food Safety and Applied Nutrition, Food and Drug Administration. Available at http://www.cfsan.fda.gov [Verified 20 December 2011]

USFDA (2001b) Guidance for Industry - fumonisin levels in human foods and animal feeds final guidance. Center for Food Safety and Applied Nutrition, Food and Drug Administration. Available at http://www.cfsan.fda.gov [Verified 20 December 2011]

USFDA (2010) Guidance for Industry and FDA: advisory levels for deoxynivalenol (DON) in finished wheat products for human consumption and grains and grain by-products used for animal feed. Available at http://www.fda.gov/Food/GuidanceComplianceRegulatory Information/GuidanceDocuments/NaturalToxins/ucm120184.htm [Verified 20 December 2011]

USFDA (2011) Compliance Policy Guides (CPG). Chapter 5 - food, colors, and cosmetics. Inspections, compliance, enforcement, and criminal investigations, US FDA. Available at http://www.fda.gov/downloads/ ICECI/ComplianceManuals/CompliancePolicyGuidanceManual/ UCM186872.pdf [Verified 1 June 2012]

van den Berg M, Birnbaum L, Bosveld ATC, Brunström B, Cook P, Feeley M, Giesy JP, Hanberg A, Hasegawa R, Kennedy SW, Kubiak T, Larsen JC, 
van Leeuwen FXR, Liem AKD, Nolt C, Peterson RE, Poellinger L, Safe S, Schrenk D, Tillitt D, Tysklind M, Younes M, Waern F, Zacharewski T (1998) Toxic Equivalency Factors (TEFs) for PCBs, PCDDs, PCDFs for humans and for wildlife. Environmental Health Perspectives 106, 775-792. doi:10.1289/ehp.98106775

van den Berg M, Birnbaum LS, Denison M, De Vito M, Farland W, Feeley M, Fiedler H, Hakansson H, Hanberg A, Haws L, Rose M, Safe S, Schrenk D, Tohyama C, Tritscher A, Tuomisto J, Tysklind M, Walker N, Peterson RE (2006) The 2005 World Health Organization reevaluation of human and mammalian toxic equivalency factors for dioxins and dioxin-like compounds. Toxicological Sciences 93, 223-241. doi:10.1093/toxsci/ kfl055

Vic. (1992) Agricultural and Veterinary Chemicals (Control of Use) Act 1992. Available at http://www.legislation.vic.gov.au/ [Verified 23 November 2012]

WA (2006) Veterinary Chemical Control and Animal Feeding Stuffs Regulations 2006. Available at http://www.austlii.edu.au/au/legis/wa/ consol_reg/vccaafsr2006581/ [Verified 20 December 2011]

Watson A, Burgess LW, Summerell BA, O'Keeffe K (2006) Fusarium spp. associated with ear rot of maize in the Murrumbidgee irrigation area of New South Wales. In 'Water to gold: Proceedings of the Maize Association of Australia 6th triennial conference. Griffiths, NSW'. pp. 127-130. (Maize Association of Australia: Darlington Point, NSW)

Wearing AH, Burgess LW (1978) Distribution and mode of survival of Fusarium roseum 'graminearum' Group 2 in maize soils of eastern Australia. Transactions of the British Mycological Society 70, 480-486. doi:10.1016/S0007-1536(78)80152-1

Webley DJ, Jackson KL (1998) Mycotoxins in cereals - a comparison between North America, Europe and Australia. In 'Stored grain in Australia. Proceedings of the Australian postharvest technical conference 1998'. (Eds HJ Banks, EJ Wright and KA Damcevski) pp. 63-66. (CSIRO Stored Grain Research Laboratory: Canberra)

Weidenbörner M (2001) 'Encyclopedia of food mycotoxins.' (Springer: Berlin)

Whitaker TB (2003) Detecting mycotoxins in agricultural commodities. Molecular Biotechnology 23, 61-71. doi:10.1385/MB:23:1:61

Whittemore CT, Macer RCF, Miller JK, Mantle PG (1976) Some consequences of the ingestion by young and growing pigs of feed contaminated with ergot. Research in Veterinary Science 20, 61-69.
Whittemore CT, Miller JK, Mantle PG (1977) Further studies concerning the toxicity of ingested ergot sclerotia (Claviceps purpurea) to young and growing pigs. Research in Veterinary Science 22, 146-150.

Williams KC, Blaney BJ (1994) Effect of the mycotoxins, nivalenol and zearalenone, in maize naturally infected with Fusarium graminearum on the performance of growing and pregnant pigs. Australian Journal of Agricultural Research 45, 1265-1279. doi:10.1071/AR9941265

Williams KC, Blaney BJ, Magee MH (1988) Responses of pigs fed wheat naturally infected with Fusarium graminearum and containing the mycotoxins 4-deoxynivalenol and zearalenone. Australian Journal of Agricultural Research 39, 1095-1105. doi:10.1071/AR9881095

Williams KC, Blaney BJ, Dodman RL, Palmer CL (1992) Assessment for animal feed of maize kernels naturally infected predominantly with Fusarium moniliforme and Diplodia maydis: I. Fungal isolations and changes in chemical composition. Australian Journal of Agricultural Research 43, 773-782. doi:10.1071/AR9920773

Williamson PM, Highet AS, Gams W, Siva-Sithamparam K, Cowling WA (1994) Diaporthe toxica sp. nov., the cause of lupinosis in sheep. Mycological Research 98, 1364-1368. doi:10.1016/S0953-7562(09) 81064-2

Wolff J (1989) Ergot in cereals. In 'Report of the practitioner information meeting, Grub, Bavaria, 14 March 1989'. pp. 28-36. (Bavarian Ministry of Food, Agriculture and Forestry)

Wolff J, Richter WIF, Spann B (1995) Mutterkornalkaloide in der Milch? VDLUFA Schriftenreihe, Kongressband 18, 515-524.

Young JC, Chen Z (1982) Variability in the content and composition of alkaloids found in Canadian ergot. III. Triticale and barley. Journal of Environmental Science and Health. Part. B, Pesticides, Food Contaminants, and Agricultural Wastes 17, 93-107. doi:10.1080/ 03601238209372305

Young JC, Marquardt RR (1982) Effects of ergotamine tartrate in growing chicken. Canadian Journal of Animal Science 62, 1181-1191. doi: $10.4141 /$ cjas $82-138$

Young LG, McGirr L, Valli VE, Lumsden JH, Lun A (1983) Vomitoxin in corn fed to young pigs. Journal of Animal Science 57, 655-664.

Zomborszky MK, Vetési F, Repa I, Kovács F, Bata A, Horn P, Tóth A, Romvári R (2000) Experiment to determine limits of tolerance for fumonisin B1 in weaned piglets. Journal of Veterinary Medicine. B, Infectious Diseases and Veterinary Public Health 47, 277-286. doi:10.1046/j.1439-0450.2000.00343.x 